\title{
Profiting From Technological Innovation by Others: The Effect of Competitor Patenting on Firm Value *
}

\author{
Anita M. McGahan \\ Everett W. Lord Distinguished Faculty Scholar \\ Strategy and Policy \\ Boston University \\ 595 Commonwealth Avenue \\ Boston, MA 02215 \\ (617) 3534289 \\ amcgahan@bu.edu
}

\author{
Brian S. Silverman \\ J.R.S. Prichard and Ann Wilson Chair in Mgmt \\ Rotman School of Management \\ University of Toronto \\ 105 St. George Street \\ Toronto, Ontario M5S 3E6 \\ (416) 9467811 \\ silverman@rotman.utoronto.ca
}

rev. July, 2006

\begin{abstract}
In 1986, Teece proposed a seminal framework for analyzing why innovators may fail to benefit from their innovations. He argued, in part, that firms with the requisite complementary assets can often expropriate an innovator's returns especially when appropriability regimes are weak. In this paper, we explore the implications of this framework from the perspective of an incumbent firm - more precisely, of investors in that firm - facing innovation by established corporate rivals and by inventors from outside its industry. We demonstrate that the financial-market value of publicly traded firms depends on patented innovation by competitors (both established rivals and industry outsiders). Our empirical study generates three main results. First, the financial-market value of an incumbent is negatively associated with "important" patenting by outside inventors. Second, in industries characterized by weak appropriability regimes or by a strong reliance on complementary assets, this relationship is reversed: important patenting by outsiders is positively associated with the incumbent's financial-market value. Third, the effect of outsiders' patented innovation on the focal incumbent is qualitatively different than that of established rivals' patented innovation on the incumbent. These results are consistent with implications of Teece (1986) and with recently developed models that formalize elements of his framework. More generally, these results support theories about both the market-stealing and spillover effects of innovation.

* Thanks to Bronwyn Hall and the NBER for sharing compiled data on patents and patent citations, and to Ken Corts, Ludovic Dibiaggio, Bronwyn Hall, David Mowery, Bert Verspagen, Minyuan Zhao, and four anonymous referees for comments. We are grateful to seminar participants at Boston University, Brigham Young University, London Business School, New York University, and the Université de Paris, and to conference participants at the Academy of Management, Atlanta Competitive Advantage Conference, DRUID, the Schumpeter Society and the SPRU symposium in honor of Keith Pavitt. For generous financial support, McGahan thanks the Dean's Office, BUILDE and the Systems Research Center at Boston University; Silverman thanks the University of Toronto and the Social Sciences and Humanities Research Council of Canada.
\end{abstract}




\section{Introduction}

Recent research demonstrates that a firm's financial-market value is positively influenced by its patented innovations (Hall, Jaffe and Trajtenberg 2005; Reitzig 2004). Yet we have little empirical evidence regarding the relationship between a firm's financial-market value and patented innovation by its rivals (exceptions include Austin 1993, 2000 and Furman, Kyle, Cockburn and Henderson 2004). Obtaining additional reliable evidence about this relationship is important in part because the influence of innovation by existing and potential rivals on a firm's financial-market value is theoretically ambiguous. On one hand, “market-stealing” effects may dominate: Patenting by a rival may generate property rights that give the rival an advantaged position in the industry, thus reducing the focal firm's financial value. On the other hand, "spillover” effects may dominate: A breakthrough by a rival may trigger greater technological opportunity for the firms in an industry, or the disclosure of innovation by a rival through patenting may provide information on which a firm can build, thus increasing the firm's financial value. ${ }^{1}$ Identifying the effects of patenting by potential rivals is further complicated by the prospect of postinnovation cooperation between the potential rival and focal incumbent firm (Gans and Stern 2000; Rothaermel 2001).

Below, we explore the influence of competitor innovation on the financial-market values of firms. We distinguish between innovation by existing corporate rivals and that by other inventors in line with theories suggesting that the relative strength of market-stealing and spillover effects differs across these two groups. Our analysis builds on three insights from theories of innovation, notably from Teece's (1986) seminal work on profiting from technological innovation. First, a focal incumbent is likely to be affected differently by the innovation of an industry outsider than by that of an existing rival (Mazzoleni and Nelson 1998). Unlike established rivals, industry outsiders often need to assemble a portfolio of assets to exploit an innovation, and can choose to access these assets by cooperating with an incumbent firm via a licensing arrangement (Teece 1986). In particular, incremental innovation by other inventors is relatively likely to be commercialized through a cooperative arrangement with incumbents that gives the outsider access to critical complementary assets but that also confers a substantial share of profits to the

\footnotetext{
${ }^{1}$ This is analogous to models of R\&D competition, in which rivals' R\&D investments produce both market-stealing effects and spillover effects (Dixit 1988; Levin and Reiss 1988).
} 
incumbent partners. As a result, the relative intensity of market-stealing effects may be dampened and the intensity of spillovers enhanced when an outside inventor is responsible for an innovation.

Second, the strength of market-stealing and spillover effects may be further influenced by the importance of the patented innovation by the rival or outsider. The incentive to cooperate (i.e., through licensing) rather than to compete with incumbents may be dampened for important innovations (Gans and Stern 2000). As an innovation’s potential to generate significant commercial value increases, the industry outsider faces a greater incentive to enter the market itself, and (because this increased incentive to enter provides bargaining power in negotiations with incumbents) the outsider may claim a greater share of the profits in the event that it licenses its innovation to an incumbent. Thus, either through direct market-stealing or indirect appropriation through licensing, the negative impact on of an outsider's important innovation on the financial-market value of a firm may be particularly strong.

Third, industries vary in appropriability regime, technological opportunity, and the importance of complementary assets (Teece 1986; Cockburn and Griliches 1988). As a result, the initial conditions for market stealing and spillovers vary across industry settings. Furthermore, the susceptibility of a focal incumbent to the compounding effects of market stealing and spillovers by innovating competitors may depend on industry conditions. For example, even an important innovation by a corporate rival or an outsider may not significantly threaten the financial-market value of an incumbent if the industry offers little opportunity to the rival for commercializing successfully. In general, the weaker the appropriability regime in an industry, the greater the likelihood that the spillover effect outweighs the market-stealing effect, and consequently the more likely that innovation by both existing rivals and other inventors will enhance a focal incumbent's market value.

Based on these insights, we predict differences in the impact of competitor innovation on the financial-market values of an incumbent firm at three levels. ${ }^{2}$ First, we expect that the identity of the innovator as either an established corporate rival or as an outsider will have a significant influence on the

\footnotetext{
${ }^{2}$ The estimation of the "value relevance" of patents has a long and vibrant history. Since Griliches (1981), many scholars have investigated the effect of a firm's own patents on its market value as measured by Tobin's q. Early studies suggested that patents do not have a significant impact on a firm's stock-market value after controlling for R\&D expenditures (Griliches 1981; Pakes 1985). Subsequent studies uncovered the systematic effects of patents on a firm's stock-market value in industries where intellectual property rights are strong (Cockburn and Griliches 1988) and when allowing for variation in patent importance through the use of patent citations (Hall et al 2005). As a result, our model is specified to account for both the direct effect of the number of patents acquired by a firm and its competitors, and the importance of these patents as measured by subsequent citations.
} 
strength of market-stealing and spillover effects and consequently on the financial-market values of firms. Second, we expect that the importance of the innovation - as measured by subsequent citations to the relevant patents - will also yield differences on the strength of incentives for market-stealing and thus influence the relative importance of market-stealing and spillover effects. Third, we expect that the strength of the appropriability regime and the importance of complementary assets in an industry will influence the strength of these effects, particularly for innovation by outside inventors.

To test these predictions, we examine innovation and market valuation of large, public firms throughout the U.S. economy over nearly two decades. We link Compustat and the NBER patent data by relying in part on a concordance that ties patents to the industries in which they are likely to be applicable. This yields a novel dataset that identifies patents granted to existing product-market rivals - that is, publicly traded firms that currently compete in a focal firm's industries - and to entities that are not currently competing as corporations in the firm's industry (“industry outsiders” according to Mazzoleni and Nelson 1998, and "outside inventors" in the language used here). We then link this dataset to the Yale Survey of Innovation (Levin, Klevorick, Nelson and Winter 1987), which enables us to incorporate information on the strength of patent protection and the importance of complementary assets across a subset of our industries.

Consistent with predictions, the analysis demonstrates that "incremental" patenting by outside inventors positively affects a focal incumbent firm’s value, while “important” patenting by outside inventors - as measured by subsequent citations - negatively affects its value. ${ }^{3}$ This last result stands in contrast to the positive impact of important patenting by existing corporate rivals on the firm's value. The effects are amplified in the presence of strong patent protection. Under weak appropriability regimes, however, most innovation - incremental or important, by existing rivals or by other inventors - has a positive effect on a focal firm's market value. This result suggests that spillover effects dominate marketstealing effects when intellectual-property protection is weak. The findings also demonstrate the central

\footnotetext{
${ }^{3}$ We are not studying the particular mechanisms by which outside inventions spill into the industry - but rather are assessing evidence on whether investors in a focal firm respond as if the outside inventions are a threat to the netpresent value of a firm's performance. Possible mechanisms that could account for the threat include (a) the outsider's successful commercialization of new products, (b) expensive licensing arrangements by the outsider to the firm and (c) licensing by the outside inventor to a rival of the firm. Our analysis makes no assumptions about whether outsiders influence specific incumbents or about relationships between outsiders and incumbents. Indeed, if outside invention influences only a few insiders, then the empirical relationships that we identify would be dampened.
} 
importance of complementary assets to the impact of competitor innovation on the firm's value. In situations where complementary assets are particularly crucial, important innovation by outside inventors has a strongly positive impact on firm value. Yet when complementary assets are not as important, then this effect disappears. Overall, the results suggest that the established structure of an industry and the identity of the inventor as an incumbent or outsider are centrally important to the value of important innovation.

This article makes several contributions to the literature that links the financial-market values of firms and innovative activity. First, although some prior studies have looked at the effect of rival patenting on a firm's market value in specific industries (e.g., Austin 2000, Furman et al 2004, and Megna \& Klock 1993) - with conflicting results - this study goes further to investigate a broad range of industries. This study is also among the first to explore variation in competitor patenting, and to consider the importance of patents by examining subsequent citations. Second, this analysis develops implications for financial-market value from the theory in Gans and Stern (2000), provides empirical support for their model, and demonstrates that the identity of the competing inventor is relevant to the effectiveness of appropriation mechanisms. Third, we contribute to the broader literature about the costs and benefits of patent protection (Mazzoleni and Nelson 1998; Cohen, Goto, Nagata, Nelson and Walsh 1999) and demonstrate that the identity and market history of inventors has important implications for the value of innovation.

The article is organized as follows. Section 2 outlines the theoretical insights that drive our predictions about the effects of competitor patenting on a focal firm's stock market valuation. Section 3 describes the data and develops a statistical model for estimating these effects. Section 4 presents the results and section 5 discusses the implications.

\section{Innovation by Rivals, IP Regime, and the Market Value of Incumbent Firms}

Theoretical and empirical models of innovation have long postulated that research effort generates two distinct effects on rivals: a market-stealing effect and a spillover effect (Levin, Cohen and Mowery 1985; Teece 1986; Merges 1997). The market-stealing effect occurs when the knowledge generated by one firm's research effort enables it to improve its products, reduce its costs, or otherwise gain a more advantageous competitive position against its rivals. The spillover effect occurs when the 
knowledge generated by one firm's research effort becomes available to other firms, thus benefiting them as well as the original firm. The act of patenting an innovation generates similar effects: a patent helps a firm legally protect its knowledge so that rivals can not copy its improved products or processes, thus generating a competitive advantage beyond that of its initial $\mathrm{R} \& \mathrm{D}$, but the disclosure involved in the patenting process diffuses knowledge about the patented innovation that may then spill over to other firms. These two effects have countervailing influences on a firm's financial-market value: the marketstealing effect implies that the rival's patenting will harm the firm, while greater spillovers imply that the rival's patenting will benefit the firm. It is not clear from the theory which effect would be dominant that is, whether patenting by other firms will on average help or harm a focal firm.

To study these issues, researchers have focused on the influence of innovation on a firm's financial-market value rather than on its profitability. The reasons relate to the asynchronous timing of innovation breakthroughs, commercialization, and profits. By examining a firm's financial-market value, the researcher relies on the incentives of investors to change their explicit and/or implicit forecasts of the present values of profits in response to information about innovations. Because investors react to information contemporaneously with its release, the financial-market values of firms change in response to the revelation of information about prospective products that occurs when patent applications are filed.

Empirical evidence on the effect of rival patenting on a firm's financial-market value has produced conflicting results. Austin $(1993,2000)$ conducts event studies around patent announcements in the biotechnology industry. He finds that the granting of a patent to a rival is, on average, associated with a positive stock-market reaction for a firm, thus suggesting that the spillover effect dominates, although less so for "high-profile” patents. Furman et al. (2004) suggest that the extent of competitor spillovers depends in part on the geographic proximity of the competitors as well as the strength of the headquarters model in the focal firm. On the other hand, Megna and Klock (1993) study the impact of rival patenting on Tobin's q for firms in the semiconductor industry and find that rival patents negatively impact a firm's financial-market value, thus suggesting that the market-stealing effect dominates. (None of these studies considers the innovation of potential rivals, focusing solely on innovation by existing rivals.)

An implication of both the theoretical and empirical research on these questions is that predictions about the prevalence of market-stealing and spillover effects must be tied to the identities of inventors and to the significance of their patents. The prior research also shows that the potential for 
market-stealing and spillover effects depends on industry structure - and in particular the appropriability regime in a particular setting.

\subsection{The importance of rivals' innovation and the market value of the focal incumbent firm}

A longstanding literature on the economics of innovation demonstrates that the incentives of an entrant to create and commercialize a product may differ significantly from those of an incumbent. The direction of these differences turns largely on the economic importance of an innovation. Reinganum (1983) showed that, when an innovation is economically important, an incumbent may not innovate aggressively even when threatened by outside inventors to protect monopolistic profits. For innovations that are economically less significant - in other words, those that pose less of an obsolescence threat to the existing business - the incumbent's incentive to innovate more closely approximates that of the entrant.

A complementary line of research suggests that an incumbent may be less capable of responding to important innovation than to economically modest innovation (Henderson 1993). An incumbent is likely to have the requisite absorptive capacity to understand and perhaps benefit from others' incremental innovation, whereas important innovation is more likely to draw on knowledge outside of the incumbent's existing technological competence (Cohen and Levinthal 1990).

These literatures imply that the importance of an outsider's innovation will directly influence the spillover effects of that innovation. If an incumbent can understand the underlying innovation and has an incentive to pursue or adopt it - which occurs most readily for modest innovations - then the spillover effect is likely to be high. Incumbents will have little incentive or competence to understand and adopt important innovations, suggesting that the spillover effect is decreasing in the importance of outsiders' innovation.

What about the market-stealing effect of innovation an outsiders? Gans and Stern (2000) suggest that this effect is greater for outsider innovations that are of greater economic importance). Their model extends Reinganum (1983) by allowing the potential entrant to exploit its innovation via licensing to the incumbent, rather than by entering the market itself. This option generates a series of predictions regarding when an innovation by a potential entrant - analogous to an "other inventor" in our study - will lead to entry and heightened competition, and when it will lead to collaboration with the incumbent. A central finding is that, as an innovation increases in economic importance, competitive entry is more 
attractive to the potential entrant. Even if the entrant ultimately agrees to license its innovation to the incumbent, the increased attractiveness of its outside option (competitive entry) requires that the incumbent must pay a higher share of the expected profits to entice the entrant to collaborate.

Thus, although conflicting theoretical predictions prevent us from making predictions about the effect of patented innovation by existing rivals on a focal incumbent firm, we are able to make predictions about the effect of patented innovation by outside inventors. For incremental innovation by outsiders, we expect the spillover effect to outweigh the market-stealing effect on average. As the importance of an outsider's innovation increases, however, we expect the spillover effect to decrease and the marketstealing effect to increase. This implies that as a potential entrant's innovation increases in importance, the impact on an incumbent's future performance is unambiguously negative. Thus we hypothesize that:

H1a: "Regular" patented innovation by outside inventors [that is, entities that are not current corporate rivals] is positively related to the market valuation of a focal incumbent firm.

H1b: The importance of patented innovation by outside inventors [that is, entities that are not current corporate rivals] is negatively related to the market valuation of a focal incumbent firm.

\subsection{Patent Appropriability Regime}

The strength of the intellectual property regime surrounding patents is likely to affect the relationship between rival innovation and a focal firm's performance. A large literature highlights the challenge facing firms that seek to innovate profitably from innovations in industries in the face of weak intellectual property protection (Teece 1986; Oxley 1997). Cockburn and Griliches (1988: 422), noting that a firm's own patents offer a more significant boost to its market value in industries that are characterized by strong appropriability, suggest that the capital market recognizes that a given R\&D or patenting effort "may have different payoffs in different appropriability environments."

The flip side of this is that, in the presence of weak protection of intellectual property rights, a firm should benefit more readily from rival innovations - innovating competitors face challenges in appropriating returns precisely because weak IP regimes permit other firms to exploit the knowledge embedded in their innovation. In environments in which patents provide strong appropriability, a focal 
firm is prevented from using the knowledge disclosed in an existing or potential rival's patent without consent of the patent owner. In such cases, the spillover effect of rivals' patenting may be severely circumscribed. As a result, all else being equal, the spillover effect associated with rivals' patenting should be greater the weaker is the appropriability regime. This is demonstrated starkly in Cohen et al.'s (2002) study of national differences in R\&D spillovers. The authors find that in Japan, where background institutions effectively provide a weaker IP regime than in the U.S., patents diffuse information and hence generate knowledge spillovers far more readily than in the U.S.

Appropriability features prominently in the Gans and Stern (2000) model as well. The strength of patent protection around an outside inventor's innovation positively affects the outsider's position and negatively affects the incumbent's position should they not reach a licensing deal. Consequently, stronger patent protection should increase the outsider's willingness to compete with rather than license to industry incumbents, and should increase the share of the profits captured by the outsider in the event that it chooses to license.

However, all else equal, the appropriability regime should not influence the competitive effect of a particular innovation. With an increase in the spillover effect and no change in the competitive effect, we expect that, on the margin, weaker patent appropriability will be positively associated with a focal firm's prospects.

H2: The weaker the intellectual property regime in an industry, the more that innovation by corporate rivals and outside inventors positively affects the market value of a focal firm in that industry.

\subsection{Importance of complementary assets}

Since Teece (1986), it has been widely accepted that complementary assets can dramatically affect the division of returns to innovation. In industries where assets such as distribution infrastructure and manufacturing capacity are crucial to the successful commercialization of technology, ownership of such assets confers an important opportunity for profit on an incumbent regardless of the source of the innovation. Conversely, an outside innovator stands to appropriate a far greater share of the returns to its innovation when it need not access specialized complementary assets in order to commercialize its innovation. 
The implication for an incumbent is clear: in industries where complementary assets are important, ownership of these complementary assets can enable a firm to appropriate at least some of the returns to innovation by industry outsiders. Tripsas (1997) shows that incumbent firms were able to exploit their ownership of complementary assets to survive the onslaught of radical innovations in the typesetter industry. Rothaermel (2001) demonstrates that incumbent pharmaceutical firms benefited from innovation by new biotechnology firms, thanks to their ownership of key complementary assets and the consequent need of the biotechnology firms to ally with the incumbents. Gans and Stern's (2000) model also demonstrates how increased importance of complementary assets (parameterized as entry costs) will increase the bargaining power of incumbents. We thus predict:

H3: The more important are complementary assets in an industry, the more that innovation by outside inventors positively affects the market value of a focal firm in that industry.

\section{Method and Data}

The dependent variable in our analysis is the firm's financial-market value, which we represent using Tobin's q, which is the ratio of the value of all financial claims on a corporation (such as stock values, bond values, etc.) to the replacement value of the firm's booked assets. Tobin's q has been widely used in the literature that relates a firm's innovative activity to its financial performance. The information here on corporate performance is compiled in a large, unbalanced panel of U.S. public firms during the period 1981-1999. ${ }^{4}$

The independent variables fall into four categories. First, we confirm the results of Hall et al. (2005) by exploring the relationship between a firm's financial-market value and its own accumulated R\&D, patenting, and citation productivity. Note that it is possible that enthusiasm for innovation among investors during the mid- to late-1990s may have escalated values of Tobin's q, and simultaneously motivated greater investments in R\&D. By relating Tobin’s q to the stocks of accumulating R\&D,

\footnotetext{
${ }^{4}$ Note that the imbalance in the panel reflects the inclusion of firms as incumbents in any year for which we have data on them during the period. This approach assures that our results do not rest on an inaccurate representation of the identity of corporate incumbents. We confirmed this empirically by estimating the models while including observations only for the firms that survived through all 19 years of our sample period. The results for this restricted set of firms are broadly similar to those reported in Table $4-46$ of the 59 reported coefficients retain their sign and significance. Of the key independent variables, OutsiderCitations retains its sign but loses significance in one model. Thus, we conclude that survivorship bias is not of significant concern.
} 
patents, and citations, we control for the asynchronous timing of investments and their returns. (Below, we explain how controls for year and firm effects address possible distortions associated with stockmarket anomalies.)

Second, we introduce a set of variables that describe the innovative activity of corporate rivals that participate in the same industries as the focal firm. The innovative activity of corporate rivals is investigated in terms of R\&D stock, patent, and citation productivity.

Third, we evaluate the innovative activity of outside inventors using information on patent stock and citation stock. Finally, some versions of the model include information on the patent appropriability regime and the salience of complementary assets in the industry. We also include year effects.

The primary source of data on corporate performance is the Compustat Basic Active and Research File database. We included in our sample any firm that appeared in the Compustat database for more than five years during this time period. This yielded a total of 4,168 firms and a sample of 42,468 firm-year observations with information for most firms on R\&D expenditures, assets, and up to ten selfreported SICs at the four-digit level.

Information on patenting in the U.S. between 1975 and 1999 was drawn from the NBER Patent Citation Data File (Hall 1999; Hall et al. 2001). This database provides most of the information available on the introductory text (i.e., the "first page") of a granted patent as well as additional information developed by Hall, Jaffe and Trajtenberg (2001) on subsequent (or “forward”) citations to the patents. We used these data to identify 1) to what entity, if any, each patent in the NBER data is assigned; 2) the year in which the patent application was filed; and 3) the number of citations that the patent received from all subsequent patents issued in the United States through 1999. Patents are often assigned to subsidiaries; we assigned patents of subsidiaries to their ultimate parents by matching subsidiaries to corporate parents using Who Owns Whom for the year 1991 and various corporate directories for the 1990s. During the 1981-1999 period, 391,059 patents were granted by the U.S. Patent and Trademark Office to the firms in our sample.

One of the central analytical challenges of this paper is the identification of outside inventions with particular industries. As described below, we accomplish this using the patent-industry concordance developed by Silverman (1999), which links U.S. patent classes to four-digit industries in which such technologies are likely to be useful. 
Below we describe the model and the variables in detail. Table 1 provides additional information on how each variable is calculated.

Specification of the Model

We analyzed the effect of existing rivals’ and other inventors’ patenting on a focal firm’s market value by estimating an extension of the patent-Tobin's q model of Hall et al. (2005), which is itself a refinement of the classic model developed by Griliches (1981). The Hall et al. (2005) model, presented as Equation (1) below, represents the basic relationship between the financial-market value of the firm and its R\&D intensity, patent intensity, and citation intensity:

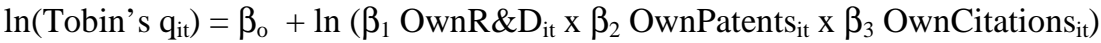

$$
\begin{aligned}
& +\beta_{4} \text { NoR\&D }_{i t}+\beta_{5} \text { NoPatents }_{\text {it }}+\Sigma_{\mathrm{t}} \beta_{\mathrm{t}} \mathrm{D}\left(\text { Year }_{\mathrm{t}}\right)+\varepsilon_{\mathrm{it}}
\end{aligned}
$$

The specification is expressed in logs to assure normality in the distribution of the error term given skew in both $\mathrm{q}_{\mathrm{it}}$ and the stock ratios. Note that if equation (1) were not taken in logs, then the terms on the right-hand-side would be multiplicative and would reduce to the ratio of citations to assets for firms with contemporaneous $R \& D$ and patenting. Equation (1) is designed to represent the relationship between the value of the firm and its own important innovative activity. The coefficients $\beta_{2}$ and $\beta_{3}$ should be interpreted as the impact of above-average patenting and/or citations - that is, the influence on firm performance of patenting above the norm given the level of $R \& D$, and the influence of citations above the norm given the level of patenting, by the firm (Hall et al. 2005).

We extend this model to include measures of existing rivals' innovative efforts and the fruits of innovative efforts by other inventors, presented in Equation (2)

$$
\begin{aligned}
\ln \left(\text { Tobin’s q }_{\mathrm{it}}\right) & =\beta_{\mathrm{o}}+\ln \left(\beta_{1} \text { OwnR\&D }_{\mathrm{it}} \times \beta_{2} \text { OwnPatents }_{\mathrm{it}} \times \beta_{3} \text { OwnCitations }_{\mathrm{it}}\right) \\
& +\beta_{4} \text { NoR\&D }_{\mathrm{it}}+\beta_{5} \text { NoPatents }_{\mathrm{it}} \\
& +\ln \left(\beta_{6} \text { RivalR\&D }_{\mathrm{it}} \times \beta_{7} \text { RivalPatents }_{\mathrm{it}} \times \beta_{8} \text { RivalCitations }_{\mathrm{it}}\right) \\
& +\beta_{9} \text { NoRivalR\&D }_{\mathrm{it}}+\beta_{10} \text { NoRivalPatents }_{\mathrm{it}} \\
& +\ln \left(\beta_{11} \text { OutsiderPatents }_{\mathrm{it}} \times \beta_{12} \text { OutsiderCitations }_{\mathrm{it}}\right) \\
& +\beta_{13} \text { NoOutsiderPatents }_{\mathrm{it}}+\Sigma_{\mathrm{t}} \beta_{\mathrm{t}} \mathrm{D}\left(\text { Year }_{\mathrm{t}}\right)+\Sigma_{\mathrm{i}} \beta_{\mathrm{i}} \mathrm{D}\left(\text { Firm }_{\mathrm{i}}\right)+\varepsilon_{\mathrm{it}}
\end{aligned}
$$

Dependent variable 
The dependent variable, Tobin's $q_{i t}$, is assessed using Compustat data following a conventional approach from the literature (e.g., Lindenberg and Ross 1981; Salinger 1984; McGahan 1999). We use annual Compustat data on the value of common stock, preferred stock, and debt to calculate financial market value for each firm-year, and data on assets, $R \& D$, advertising, and other relevant items to construct stocks of tangible and intangible assets. Appendix A provides additional details on the construction of this measure. Note that patents are not reflected on a firm's balance sheet except under specialized conditions (i.e., when firms make acquisitions of other companies that have valuable patents and where the purchase price reflects this value and where purchase accounting is used to book the merger). Thus, an increase in Tobin's q occurs when investors anticipate that a firm's overall value is greater because of valuable innovation.

\section{Independent variables}

To assess the influence of innovation on financial-market performance, we construct a number of independent variables that represent the stock of knowledge capital within a firm, within its corporate rivals, and among outside inventors. The stocks of knowledge - rather than the levels of new knowledge - are relevant because the dependent variable, Tobin's q, represents the overall financial value of the firm. Hall et al. (2005: 24) explain that "once R\&D is observed, the market presumably knows how to price the expected value of the innovative stream that will results from it, including the expected number of patents and citations that will come further down the line.... Thus, the additional information value of patents once $R \& D$ has already been factored in must reside in the number of patents per dollar of R\&D. [In turn,] the informational value of citations once patents have been factored in must lie in the extent to which the number of received citations per patent deviates from expectations.”

The independent variables directly associated with the hypotheses are OutsiderPatents $\mathrm{it}_{\mathrm{it}}$ OutsiderCitations $_{\mathrm{it},}$ PatentAppropriabilityRegime $_{\mathrm{it}}$, and ComplementaryAssetRegime $\mathrm{it}_{\mathrm{it}}$. Other independent variables that are useful in interpretation of these are RivalPatents ${ }_{\mathrm{it}}$ and RivalCitations $\mathrm{it}_{\mathrm{it}}$. The relevance of these variables depends on several others, and consequently the explanation here proceeds through each of the four categories of variables in turn.

The firm's own innovative activity 
The first class of independent variables relates to the firm's own innovative activity. These variables are important controls for our hypotheses 1, 2, and 3 and also confirm the results obtained by Hall et al (2005).

$\underline{\text { OwnR\&D }}_{\mathrm{it}}$ is defined as the stock of R\&D investment of firm $\mathrm{i}$ at the end of year $\mathrm{t}$ divided by the asset stock of firm $\mathrm{i}$ at the end of year t. Compustat provides firm i's annual expenditure on R\&D in each year t. We calculate the R\&D stock of firm $\mathrm{i}$ at the end of year $\mathrm{t}$ as follows:

$$
R \& D \text { Stock }_{\text {it }}=R \& D_{\text {it }}+(1-\delta) R \& D \text { Stock }_{\text {it }-1}
$$

Following prior literature (e.g., Hall et al. 2005) we set $\delta=0.15$. Thus, the R\&D stock represents the sum of all reported R\&D expenditures by firm i from 1971 through t depreciated at 15\% per year. Compustat also provides data on firm i's total assets at the end of year $t$. We divide the R\&D Stock by total assets to generate $O w n R \& D_{i t}$. Prior research has found that a firm's own R\&D intensity is positively related to its market value.

OwnPatents $\mathrm{s}_{\underline{\underline{i}}}$, represents the productivity of the firm at generating patents given its accumulated knowledge capital and is defined as the patent stock of firm $i$ at the end of year t divided by the R\&D stock of firm i at the end of year t. The numerator of this measure is derived from firm i's patent portfolio as follows. First, we tabulate the number of patents applied for by firm i in each year. Although our study begins in 1981, we collected data for patents back to 1975 to properly construct patent stocks. ${ }^{5}$ Next, for each year, we calculated firm i’s patent stock as:

$$
\text { Patent } \text { Stock }_{\mathrm{it}}=\text { Patents }_{\mathrm{it}}+(1-\delta) \text { Patent Stock }_{\mathrm{it}-1}
$$

Again, we set $\delta=0.15$. We then divide Patent Stock $\mathrm{it}_{\mathrm{it}}$ by R\&D Stock $\mathrm{it}_{\mathrm{it}}$ to generate OwnPatents $\mathrm{i}_{\mathrm{it}}$. Prior studies have found only a weak positive relationship between a firm's own patenting intensity and its market value (Hall et al (2005)).

OwnCitations $_{\text {it }}$ is defined as the stock of future citations to firm i's patent stock at the end of year $\mathrm{t}$ divided by the patent stock of firm $\mathrm{i}$ at the end of year $\mathrm{t}$. First, for each patent that firm $\mathrm{i}$ applies for in a given year, we tabulate the number of times that patent is ultimately cited through 1999 . We then sum the citations to patents in a given year. Next, for each year we calculate firm i's citation stock as the sum of the future citations to its new patents in that year plus the cumulative stock of prior patents' future

\footnotetext{
${ }^{5}$ It is difficult to collect comparable patent data before 1975, which is why we do not incorporate patent data back to 1971 to match our R\&D stock data. Our results do not change if we calculate R\&D stocks from 1975 forward rather than from 1971 forward.
} 
citations, with prior patents' future citations depreciated by 15\% per year. Finally, we divide the citation stock by Patent Stock $\mathrm{i}_{\mathrm{it}}$. Prior studies have found a firm's own citation intensity to be positively related to its market value (Hall 1999; Hall et al 2005).

$\underline{\text { NoR\&D }}_{i t}$ and NoPatents $\underline{\underline{t}}_{\underline{t}}$ are categorical variables set equal to 1 if firm i had no R\&D expenditure or no patent applications, respectively, in year $t$, and 0 otherwise. We include these measures to control for the possibility that the capital markets treat differently those firms that have absolutely no investment in innovation or innovative output in a given year.

\section{Innovation by Corporate Rivals}

The second class of variables relates to innovative activity by corporate rivals. The identification of corporate rivals is straightforward because corporations report in Compustat their activity by four-digit SIC code. We identify corporate rivals using both a narrow and broad assessment of relevance to the focal firm. The Compustat reports provide information on up to ten SIC classes of operation - one primary class and up to nine secondary classes - for each firm in each year. Under the narrow conception of industry boundaries, corporate rivals are identified as all firms with a primary SIC that is the same as firm i’s primary SIC. Under the broad conception, corporate rivals are identified as all firms for which any SIC class - primary or secondary - is the same as any of firm i's primary or secondary SICs. Empirically, the broadening of industry definition does not increase the number of corporate rivals much, which is consistent with the possibility that most outside inventors that patent in a firm's industry are not other public corporations.

RivalR\& $D_{i t}$ is defined as the average stock of $R \& D$ investment of firm i's corporate rivals at the end of year $t$ divided by the asset stock of those rivals at the end of year $t$. For each firm $\mathrm{j}$ in the set of rivals, we calculate R\&D Stock $\mathrm{j}_{\mathrm{jit}}$ and total assets $\mathrm{j}_{\mathrm{jit}}$ analogously with R\&D Stock $\mathrm{it}_{\mathrm{it}}$ and total assets $\mathrm{s}_{\mathrm{it}}$. We then calculate RivalR\&D $\mathrm{D}_{\mathrm{jt}}$ as:

$$
\text { RivalR \& } D_{i t}=\frac{\sum_{j} R \& \text { DStock }_{j i t}}{\sum_{j} \text { totalassets }_{j i t}}
$$


We thus construct two separate measures of RivalR\&D, one for the narrow definition of rivalry and one for the broad definition of rivalry. Prior research has found mixed results for the effect of Rival R\&D intensity on a focal firm’s market value.

$\underline{\text { InteractR\& }} \mathrm{D}_{\underline{i t}}$ is an interaction term between $O w n R \& D_{i t}$ and RivalR\& $D_{i t}$. Prior research suggests that competition can lead to either a positive or negative interaction between a firm's R\&D and the R\&D expenditures of its rivals. One reason may be due to spillovers: strong spillovers across direct rivals leads to a negative interaction when one firm gains expertise that benefits others or to a positive interaction when competitors share the burden of competitive externalities (see Jaffe 1989 for a discussion). Another reason may be related to technological opportunity: industries that offer significant opportunity may host firms that each invest in R\&D in an effort to tap the benefits of invention (leading to a positive $R \& D$ interaction) or that differentially invest in $R \& D$ as one rival pulls ahead (leading to a negative R\&D interaction). We control for the interaction between the firm's own R\&D and the rival's $R \& D$ to shed light on the strength of spillover and competitive effects and control for their influence on the inputs to the productive process.

$\underline{\text { RivalPatent }}_{\underline{i t}}$ represents the productivity of corporate rivals in generating patents, and is defined as the patent stock of firm i's corporate rivals divided by their R\&D stock at the end of year t. It is constructed analogously with RivalR\&D for corporate rivals under both the narrow and broad conceptualizations of industry. Patenting by corporate rivals generates two opposing effects on a focal firm's expected performance: a competitive effect that may harm the focal firm and a spillover effect that may improve the focal firm's value.

$\underline{\text { RivalCitations }} \underline{\underline{i}}$, represents the productivity of corporate rivals in generating important patents, and is one of the central variables of the analysis because we can compare its coefficient to that of OutsiderCitations $_{\text {it }}$ to better understand the test of our predictions about OutsiderCitations $\mathrm{it}_{\text {. }}$ RivalCitations $_{i t}$ is defined as the stock of future citations to the patent stock of corporate rivals at the end of year $t$ divided by the patent stock of the corporate rivals at the end of year $t$. It is constructed analogously with OwnCitations $s_{\text {it }}$ under both the narrow and broad conceptualizations of industry as the accumulated number of citations by rivals (depreciated in the same way as OwnCitations $\left.\mathrm{it}_{\mathrm{it}}\right)^{6}$

\footnotetext{
${ }^{6}$ Note that all variables on rival innovation, including RivalCitations $s_{\mathrm{i}}$, omit the influence of the focal firm. For example, the number of RivalCitations excludes citations by the focal firm on patents by rivals.
} 
$\underline{\text { NoRivalR\&D }}_{\text {it }}$ and $\underline{\text { NoRivalPatents }}_{\text {it }}$ are categorical variables set equal to 1 if corporate rivals had no R\&D expenditure or no patent applications, respectively, in year t, and 0 otherwise. These measures controls for the unique capital market reaction in situations where corporate rivals had no investment in innovation or innovative output in a given year.

\section{Innovation by Outside Inventors}

The central focus of this paper is on the influence of invention by entities that are not corporate rivals on the firm's financial-market value. To construct the variables in this category, we evaluate all patents that are tied by the Silverman (1999) concordance to the focal firm’s industry (which we conceptualize both narrowly and broadly following the conventions described earlier) but that are not tied to corporate rivals or the firm itself. These patents are held, for example, by universities, basement scientists, individuals, public corporations, private firms and governments. Because information on accumulated $R \& D$ is not available for these entities, we cannot construct a measure of OutsiderR\& $\mathrm{D}_{\mathrm{it}}$. However, using the industry's total assets as reported in Compustat as a benchmark, we can assess the patent and citation stock analogously to OwnPatents $\mathrm{s}_{\mathrm{it}}$ and OwnCitations $\mathrm{it}_{\mathrm{it}}$.

OutsiderPatents $_{\text {it }}$ is defined as the stock of patents assigned to "other inventors” not currently operating in firm i's industry/ies at the end of year t, divided by the total assets in the industry. This variable includes all patents that are relevant to firm i's industries and that are not owned by firm i's corporate rivals. We first identify the narrow and broad conceptualizations of industry for firm i, as described above. We then remove from the NBER Patent Data all patents that are assigned to firm i's corporate rivals or the firm itself, thus retaining only the patents assigned to entities that are not currently corporate rivals of firm i. The challenge is to identify how many of the remaining patents are relevant to firm i’s industries.

Although the U.S. Patent and Trademark Office assigns patents to technology-based patent classes, it does not assign patents to industries of likely applicability. This creates a central challenge for this analysis, which is to tie each technology class to an industry. We accomplish this using the method developed in Silverman (1999), which takes advantage of the fact that the Canadian Patent Office between 1978 and 1994 assigned patents both to a patent class and to SICs where they are likely to be applied (Ellis 1981). We generate a frequency distribution that associates patent classes with four-digit SIC codes to which the patents were assigned by the Canadian examiners. We then apply this frequency 
distribution to the U.S. patents assigned to entities that are not firm i or corporate rivals of firm i. Appendix B describes the concordance in detail, and addresses the limitations associated with this method. Hypothesis 1a predicted that incremental patented innovation by outside inventors will positively affect a focal incumbent firm's market value. We therefore expect the coefficient on OutsiderPatents to be positive and significant.

OutsiderCitations $_{\text {it }}$ is defined as the stock of future citations to patents assigned to "other inventors" at the end of year t, divided by the patent stock of other inventors. It is constructed analogously with RivalCitations ${ }_{i t}$, based on the outsider patents identified above. Hypothesis 1b predicted that the importance of patented innovation by outside inventors will negatively affect a focal incumbent firm's market value. We therefore expect the coefficient on OutsiderCitations to be negative and significant.

NoOutsiderPatents $_{\text {it }}$ is a categorical variable set equal to 1 if outside inventors had no patent applications in year t, and 0 otherwise.

\section{Patent Appropriability and Complementary Asset Regimes}

The theories outlined earlier that stipulate the strength and influence of competitive and spillover effects depend on the industry structure. The first element of industry structure that is particularly relevant to the strength of patenting by rivals - both corporate insiders and outsiders - is the patent appropriability regime. Hypothesis 2 stipulates that, in industries where patents are strongly enforceable, then the competitive threat associated with rival innovation may be particularly great and we expect important rival innovation by both corporate competitors and outside inventors to have a strong and negative influence on the focal firm's financial-market value.

The second element of industry structure that is relevant relates to the importance of complementary assets. Hypothesis 3 argues that, in industries that are highly reliant on complementary assets, incumbents (who presumably have these assets) will be in a strong bargaining position vis-à-vis outside inventors. Thus, we expect important innovation by outside inventors to have a positive influence on the focal firm's financial-market value in industries characterized by heavy reliance on complementary assets. Hypothesis 3 requires an examination of the estimated coefficient on OutsiderCitations $\mathrm{it}_{\mathrm{it}}$ in industries where complementary assets are important, and suggests that spillover effects may be particularly strong in these environments. 
We assess the strength of patent appropriability and complementary assets by industry using information reported in Levin et al’s (1987) Yale survey of corporate R\&D executives.

Patent Appropriability Regime $_{\mathrm{i}}$ is defined as the strength of patent protection in industry $\mathrm{j}$. In the Yale Survey of senior R\&D executives at several hundred large U.S. firms in the mid-1980s, Levin et al. (1987) asked each respondent to rate on a seven-point scale, for his/her line of business, the importance of patent protection (among other mechanisms) for appropriating the returns to innovation. We set Patent Appropriability Regime ${ }_{j}$ equal to the mean response for all respondents from industry $\mathrm{j}$ in the Yale Survey. Hypothesis 3 predicts that competitors' patenting activity of all types will be more likely to enhance a focal firm's financial-market value as patent protection is weakened. To test this, we use Patent Appropriability Regime to divide our sample into above-average patent protection and belowaverage patent protection subsamples. Gans and Stern's (2000) model predicts that an incumbent’s profitability should be decreasing in the strength of IPRs, since stronger IPRs enhance the entrant's bargaining position. More generally, Cockburn and Griliches (1988) and others argue that the fruits of innovation are more likely to generate spillovers the weaker are IPRs. Thus, as in H2, we expect to find that patenting by both existing and potential rivals has a significant and positive effect on a focal firm’s market value in the below-average patent protection subsample as compared to that in the above-average patent protection subsample.

Complementary Assets $\mathrm{j}_{\mathrm{j}}$ is defined as the importance of sales and service activities in industry $\mathrm{j}$. In the Yale Survey, Levin et al. (1987) asked each respondent to rate on a seven-point scale, for his/her line of business, the importance of Sales and Service activities for appropriating the returns to innovation. ${ }^{7}$ We set Complementary Assets $\mathrm{j}_{\mathrm{j}}$ equal to the mean response for all respondents from industry $\mathrm{j}$ in the Yale Survey. Hypothesis 3 predicted that patenting activity of outside inventors will be more likely to enhance a focal firm's financial market value as the importance of complementary assets increases. To test this, we use this variable to divide our sample into above-average importance of complementary assets and below-average importance of complementary assets subsamples. We expect to find that both normal and important patenting by other inventors have a more positive effect on a focal

\footnotetext{
${ }^{7}$ This clearly measures only one class of complementary assets. But assets related to sales and service activities play a central role in theoretical and empirical expositions on complementary assets (i.e., GE's sales force in CAT scanners (Teece 1986) or pharmaceutical firms' sales and marketing assets in partnerships with biotechnology firms (Pisano 1990; Rotharmael 2001). To the extent that our measure excludes key complementary assets, we are likely to bias our results toward insignificance.
} 
firm's market value in the above-average-importance-of-complementary-assets subsample than in the below-average subsample.

Year Controls. Year\# (where \# represents each year in our study) is a vector of fixed effects to control for variation in macroeconomic conditions and for the fact that more recent patents have a shorter window during which to generate citations. We also control for time-invariant firm effects as described in note (a) of Tables 4 and 5.

[INSERT TABLE 2 HERE]

Table 2 provides information on the dataset. Column 3 shows the average financial-market returns of the 4,168 publicly traded firms between 1981 and 1999 that applied for a patent at least once between 1975 and 1999. All firms traded on U.S. markets are included regardless of whether the firm is incorporated in the United States. The average value of Tobin's q over the whole period is 2.10, which is comparable to the average estimated in prior studies that cover similar periods (e.g., Lang and Stulz (1994) and McGahan (1999)). Columns (3) through (5) report on the average R\&D stock, patenting, and citation productivity of the firms in the sample. The stocks of patents and of citations drop dramatically in the latter years of the period because there are only a few years during which the patent can be cited. The table also reports on the numbers of firms with no contemporaneous $R \& D$ or patenting in each year. The IBM Corporation had more patent applications (a total of 15,350) and more citations $(100,923)$ than any other firm. Its rivals included Intel in semiconductor manufacturing, Hewlett-Packard and Dell in computing, and Andersen Consulting in services. The final columns of Table 2 report on the average number of rivals identified using the narrow and broad methods. Note that the number of rivals declines in the last three years, perhaps because the introduction of business-methods patenting led to patents in less-populated industries.

\section{[INSERT TABLE 3 HERE]}

Table 3 shows the correlation between the different variables under both the narrow and the broad conceptualizations of industry. As documented in prior studies, a firm's own R\&D expenditures are highly correlated with its financial-market value (Griliches 1981). The citation variables for the firm, the corporate rivals and the outside inventors are correlated at a significant level for the narrow industry definition but not at more than $37 \%$. For the broad industry definition, the correlation between the 
citation variables is much lower. As noted below, the results of our analysis are robust across the narrow and broad industry conceptualizations, which confirms that correlation between the variables is not a significant factor in their significance.

\section{Empirical Results}

Table 4 presents results from various estimations of our model. Model 1 shows the results of estimation of equation (1), which replicates Hall et al. (2005). Although our sample covers a longer period of time and a wider range of industries than theirs (notably, we include non-manufacturing industries), the estimated coefficients are similar to theirs in sign, significance and magnitude. Specifically, OwnR\&D and OwnCitations are positively associated with a focal firm's market value. The coefficient for NoR\&D is consistently and significantly negative, indicating that firms that spend zero dollars on R\&D are perceived differently by investors than those that do at least some R\&D investment. The main difference between our results and those of Hall et al. (2005) is that our coefficient on OwnPatents is not statistically significant. The portion of total variance explained is about $15 \%$, which is comparable to the level obtained by Hall et al (2005).

Model 2narrow introduces the terms related to existing corporate rivals into the model represent in equation (2), where the identification of corporate rivals is based on the narrow definition of industry boundaries. The coefficients for OwnR\&D and OwnCitations retain their signs and significance, and are virtually unchanged in magnitude. Total variance explained increases from .1518 to .1612, which indicates that about $1 \%$ of variation is $q$ is tied to the influences of innovation by corporate rivals. The coefficient for RivalR\&D is positive, indicating that a focal firm's market value is higher when corporate rivals expend significantly on $\mathrm{R} \& \mathrm{D}$. This result is consistent with the results from prior research (eg, Jaffe 1986, 1989) which suggests that technological opportunity varies across industries. The coefficient on RivalPatents is positive but not significant, suggesting that regular patenting by rivals may generate spillovers, but that these spillovers are not significant. The coefficient on RivalCitations is positive and significant, which suggests that spillover effects dominate market-stealing effects when important innovation originates with a corporate rival that competes in the same industry as the focal firm.

Model 3narrow introduces the crucial independent variables for testing Hypotheses 1a and 1b, namely, OutsiderPatents and OutsiderCitations. The coefficient for OutsiderPatents is positive and 
significant at the $90 \%$ confidence level, indicating that incremental patented innovation by outsiders positively affects a focal firm's market value. The coefficient for OutsiderCitations is negative and significant at the $99 \%$ level. As the patented innovation by outsiders increases in importance, the focal firm's value decreases. These results support the predictions of H1a and H1b, and are consistent with Gans and Stern's (2000) model of innovation, suggesting that 'regular' patented innovation by outsiders spills over to incumbents (presumably through licensing) but that market-stealing effects dominate for important innovation.

The difference in the signs of the estimated coefficients for RivalsCitations and OutsiderCitations underscores the fact that the identity of the innovator matters. When highly cited patents are developed by existing corporate rivals, the effect on the focal firm's value is positive, which suggests that spillovers dominate market-stealing effects (contrary to the result on significant innovation by outsiders). A focal firm may better understand and respond to important innovation by corporate rivals, with which it may share absorptive capacity, than to such innovation by outside inventors. Important innovation by existing corporate rivals may also be competence-enhancing for incumbents, whereas innovation by outside inventors tends to be competence-destroying (Anderson and Tushman 1990). Regardless of the interpretation, this empirical result suggests that the established industry structure protects incumbents but not outsiders. Investors appear to interpret important invention by other entities as a threat to the firm that cannot be appropriated in the same way as ordinary invention. This is consistent with a long line of research emphasizing the ability of new entrants to exploit radical innovation to unseat successful incumbents (Reinganum 1989).

The coefficients for all other variables in Model 3narrow remain are the same in sign and similar in magnitude to those in Model 2narrow with the exception of the NoR\&D dummy. Note also that the coefficient on the interaction between the firm's own R\&D and the corporate rival's R\&D is negative and significant. The negative value of the interaction term may reflect the potential for spillovers across corporate rivals (i.e., the independent influences of the firm's own R\&D and the corporate rival's R\&D are each positive and significant, and thus the interaction may reflect spillovers). The potential for spillovers may also account for the change in sign on the NoR\&D variable in Model 3narrow, since even firms with no contemporaneous R\&D may benefit from the technological advances of rivals. 
Models 2broad and 3broad show the results of models estimated on datasets in which corporate rivals are identified using broad industry definitions. The signs of the estimated coefficients are the same as in the models applied to the narrow industry definition. The magnitudes and significance of the coefficients are also similar except for the variables associated with outside inventors. In particular, the coefficient on OutsiderPatents is significant at the $95 \%$ level instead of only the $90 \%$ level, and the coefficient on OutsiderCitations is lower in absolute value than in the model that relies on the narrow industry definition. ${ }^{8}$ This difference in the value of the estimated coefficient may arise because the market-stealing effects of significant innovation are dampened when outside invention is farther afield from the incumbent's main activities. ${ }^{9}$

We test hypotheses 2 and 3, on the influence of the appropriability and complementary-asset conditions, by incorporating information from the Yale Survey (Levin et al. 1987), as noted above. This survey covers roughly half of U.S. manufacturing industries. To test Hypothesis 2, on the appropriability environment, we divide the observations for which we have information into high- and lowappropriability subsamples. The results are reported in Table 5. The first two columns show the results for models estimated on industries characterized by strong appropriability (i.e., intellectual-property rights or IPRs), while columns 3 and 4 represent the results for industries that are characterized by weak appropriability.

The results on the innovative activity of the firm and of its corporate rivals as reported in columns 1 through 4 of Table 5 are consistent with the main results. The coefficient on the citation intensity of corporate parents is positive and significant regardless of appropriability regime. This means that spillover effects dominate market stealing effects when the innovation is owned by a corporate incumbent regardless of the appropriability regime. Note that the magnitudes of the coefficients do vary

\footnotetext{
${ }^{8}$ It is possible that our inability to measure R\&D stocks of other inventors, and consequently to measure OutsiderPatents in an identical manner as RivalPatents, in part yields the weakly positive estimated coefficient on the OutsiderPatents variable. To address this concern we re-estimated models 3narrow and 3broad after omitting RivalR\&D and replacing RivalPatents with an alternate variable, RivalPatents/Assets, that was constructed analogously with OutsiderPatents. In these models, RivalPatents/Assets retained its negative coefficient, although this coefficient is without significance in the 3broad model. All other coefficients retained their sign, significance, and magnitude. Thus, the results on OutsiderPatents do not seem to be related exclusively to the omission of a variable representing OutsiderR\&D.

${ }^{9}$ Appendix C describes the results using models that include industry effects. As explained in the Appendix, the purpose of this analysis is to explore whether the effects of patent intensity and citation intensity tend to be uniform across corporate rivals and other entities. The findings do not reject the hypothesis that the influence is uniform and provide additional support for the conclusion that industry structure and appropriately regime are central in the impact of rival innovation on the protagonist firm.
} 
across appropriability regimes (estimated at 0.094 and 0.093 in high-appropriability industries and 0.050 and 0.051 in low-appropriability industries, and statistically significantly different from each other). Thus, the positive influence of significant innovation by corporate rivals in high-appropriability industries is greater than in low-appropriability industries. This is the opposite of our expectation in Hypothesis 2.

In contrast, the effect of appropriability regime on outsider innovation is consistent with our predictions in Hypothesis 2. The results in columns 1 through 4 of Table 5 show that the effect of important patenting by an outside inventor depends on the appropriability regime. OutsiderCitations has a negative effect on the firm's value (with significance at the 95\% level when the industry is defined broadly) for high-appropriability industries (such as pharmaceuticals and semiconductors), which suggests that market-stealing effects dominate spillover effects in environments where IPR is protected (a result consistent with Gans and Stern 2000). Yet in the low-appropriability models, the coefficient for OutsiderCitations is positive and significant. This suggests that when the appropriability regime is weak, an outside inventor's important innovation is likely to spill over to a focal incumbent. These differences provide evidence in support of Hypothesis 2 with respect to outsider innovation. Overall, then, we find mixed support for Hypothesis 2: a stronger intellectual-property environment is associated a more negative relationship between outsiders' important innovation and a focal incumbent's value, but is also associated with a more positive relationship between corporate rivals' important innovation and the focal incumbent's value.

The results of models that test Hypothesis 3 on Complementary Assets are presented in columns 5 through 8 of Table 5 . Columns 5 and 6 show the results for industries in which complementary assets are of above-average importance to appropriating returns on innovation, while columns 7 and 8 show the results for industries in which complementary assets are of below-average importance.

When complementary assets are important, OutsiderCitations becomes positively and significantly related to the focal incumbent's financial-market value. This means that spillover effects dominate competitive effects even when the innovation originates outside the group of corporate rivals under conditions of high complementary assets, and provides a striking contrast with the main results presented earlier and with the results on high appropriability environments. In contrast, when complementary assets are not important, OutsiderCitations has an insignificant coefficient. The difference in results across situations where complementary assets are strong and weak provides powerful 
evidence in support of Teece's (1986) claims about the centrality of complementary assets to the commercialization of innovation. Note that variation in the complementary asset regime has no impact on RivalCitations, which has essentially the same coefficient across all four models as represented in columns 5 through 8.

These results offer support for H3: when complementary assets are particularly important, incumbent firms are particularly well-situated to bargain with outside innovators to license innovations on favorable terms, thus enhancing their financial-market value. Since existing corporate rivals presumably already own relevant complementary assets, the importance of the complementary assets does not systematically affect the relationship between existing rivals' innovation and the focal firm's valuation.

Several other regularities are apparent in Table 5. In situations where complementary assets are strong, regular patenting by both corporate rivals and outside investors has a significantly negative relationship on a firm's financial-market value. This may occur because of strategic patenting by rivals and outsiders to depress a firm's financial-market value (an approach sometimes described as creating a “thicket of patents”). This relationship does not arise under high-appropriability situations, which may mean that strategic patenting is not effective in situations where investors are accustomed to valuing patents. Additional research is needed to explore these possibilities.

\section{Summary and Conclusion}

In his 1986 paper, David Teece explored the question: under what conditions does a firm profit from its own innovation? In this paper we have explored a related question: under what conditions does a firm profit from innovation by others? We analyzed how the financial-market value of an incumbent firm depends on rival innovation at a number of levels. The analysis delivers several important findings. First, we confirm results from prior studies showing that a focal firm's value depends on its own innovative activity as represented by its citation productivity. Second, focal firm value is positively associated with outside inventors' "regular” patented innovation, and negatively associated with important patented innovation by outsiders. This result stands in contrast with the importance of patented innovation by existing corporate rivals, which positively affects the focal firm's value. Third, the effect of rival innovation on a focal firm's value depends on the appropriability regime and complementary asset regime in which the firm is located. When intellectual property rights are particularly strong (i.e., when appropriability is high), the negative effect of outsiders' innovation is more pronounced, but when 
intellectual property rights are weak, outsider innovation enhances the focal firm's value. Conversely, when complementary assets are prevalent, important innovation by outsiders is positively related to the focal firm's value, but when complementary assets are not prevalent then there is no statistically significant relationship between important outsider innovation and the firm’s value.

Overall, the results support the idea that investors expect market-stealing effects to dominate spillover effects when outside inventors develop important innovations that are applicable to a focal firm's industry, except under conditions of low appropriability or high complementary assets. Under these exceptions, investors expect spillover effects to dominate. These results are consistent with Teece (1986) and with implications of Gans and Stern's (2000) model of technological competition between an incumbent and potential entrant.

The analysis has limitations. First, although the focus on multiple industries suggests that the results have generality, the breadth of the study necessitates that we have less detail on each sample firm than would be possible in an industry-specific study. Second, patent data are not comprehensive measures of innovation despite their wide use in the literature on technological innovation. We believe that future research on alternate measures of innovation and even additional patent statistics (see for example Reitzig 2004) will yield new insights on the relationships between rival innovation and a firm's financial-market value. The measure of the importance of a patent used here - namely, the number of citations in subsequent patent applications - captures only one dimension of important innovation. Alternate measures could include the number of claims, the patent "family" size, or the "shock" associated with forward citations (Hall et al 2005). Finally, the “outside inventors” analyzed here include independent inventors, government laboratories, universities, small firms, and large corporations that are not currently in the focal firm's businesses. Some entities on this list are more likely than others to behave like Gans and Stern's (2000) potential entrants. Future research could make headway by analyzing the separate effects of invention by each type of outsider.

Teece’s (1986) analysis of complementary assets and appropriability regimes sparked many important studies that explore the conditions that surround innovation. The majority consider the challenges facing an innovator in the process of accessing and building the complementary assets necessary to innovate successfully (.e.g, Pisano 1990; Oxley 1997; Arora and Merges 2004). Some studies (such as Tripsas’s (1997) investigation of the typesetter industry) deal with the reliance of 
incumbents on complementary assets for survival in the face of important innovations by potential entrants.

This analysis adds to yet another branch of literature inspired in part by Teece (1986) that addresses how incumbents benefit from outsider innovation (e.g., Rothaermel 2001; Dushnitsky and Lenox 2005). The central contribution is to demonstrate how the financial-market values of incumbent firms across the entire US economy change with innovation by existing and potential rivals. As Teece (1986) suggested, incumbent firms often can benefit from innovation by rivals - and especially when an industry structures supports significant complementary assets and offers effective appropriation mechanisms. 
Table 1: Variable Definitions

\begin{tabular}{|c|c|c|c|}
\hline Variable & Variable & & \\
\hline Name & Description & Notes & Source \\
\hline Tobin's q & Tobin’s q & $\begin{array}{l}\text { Tobin's q for firm i in year } t \\
\text { calculated as the ratio of the market } \\
\text { value of financial claims on firm i } \\
\text { divided by the replacement value of } \\
\text { firm i's assets in year t (see Appendix } \\
\text { A) }\end{array}$ & Compustat \\
\hline OwnR\&D $_{\text {it }}$ & Own R\&D Stock & $\begin{array}{l}\text { The R\&D stock of the firm in year } t \\
\text { accumulated from } 1971 \text { with annual } \\
\text { R\&D expenditures depreciated at } 15 \% \\
\text { per year }\end{array}$ & Compustat \\
\hline Assets $_{\text {it }}$ & Firm Assets & The total assets of the firm in year $t$ & Compustat \\
\hline OwnPatents $_{\text {it }}$ & Own Patenting & $\begin{array}{l}\text { The patent stock of the firm in year t } \\
\text { accumulated from } 1975 \text { with annual } \\
\text { patent counts depreciated at } 15 \% \text { per } \\
\text { year }\end{array}$ & $\begin{array}{l}\text { NBER Patent Citation } \\
\text { Data File }\end{array}$ \\
\hline OwnCitations $_{\text {it }}$ & $\begin{array}{l}\text { Own Citation } \\
\text { Productivity }\end{array}$ & $\begin{array}{l}\text { The stock of citations to the patents } \\
\text { held by the firm in year t accumulated } \\
\text { from } 1975 \text { with annual citations } \\
\text { depreciated at } 15 \% \text { per year }\end{array}$ & $\begin{array}{l}\text { NBER Patent Citation } \\
\text { Data File }\end{array}$ \\
\hline RivalR\&D $_{\text {it }}$ & $\begin{array}{l}\text { Corporate Rival R\&D } \\
\text { Stock }\end{array}$ & $\begin{array}{l}\text { The total stock of R\&D expenditures } \\
\text { among all of firm i’s rivals in year t } \\
\text { accumulated from } 1971 \text { and } \\
\text { depreciated at } 15 \% \text { per year }\end{array}$ & Compustat \\
\hline RivalAssets $_{\text {it }}$ & $\begin{array}{l}\text { Corporate Rival Asset } \\
\text { Stock }\end{array}$ & $\begin{array}{l}\text { The total stock of assets among firm } \\
\text { i's rivals in year } t\end{array}$ & Compustat \\
\hline RivalPatents $_{\text {it }}$ & $\begin{array}{l}\text { Corporate Rival } \\
\text { Patenting }\end{array}$ & $\begin{array}{l}\text { The total stock of patents among firm } \\
\text { i's rivals in year } t \text { accumulated from } \\
1975 \text { and depreciated at } 15 \% \text { per year }\end{array}$ & $\begin{array}{l}\text { NBER Patent Citation } \\
\text { Data File }\end{array}$ \\
\hline RivalCitations $_{\text {it }}$ & $\begin{array}{l}\text { Corporate Rival Citation } \\
\text { Productivity }\end{array}$ & $\begin{array}{l}\text { The total stock of citations among } \\
\text { firm i's rivals in year t accumulated } \\
\text { from } 1975 \text { and depreciated at } 15 \% \text { per } \\
\text { year }\end{array}$ & $\begin{array}{l}\text { NBER Patent Citation } \\
\text { Data File }\end{array}$ \\
\hline OutsiderPatents $_{\text {it }}$ & $\begin{array}{l}\text { Outside Inventor } \\
\text { Patenting }\end{array}$ & $\begin{array}{l}\text { The total stock of patents in the } \\
\text { industry but not associated with firm I } \\
\text { or its rivals accumulated from } 1975 \\
\text { and depreciated at } 15 \% \text { per year }\end{array}$ & $\begin{array}{l}\text { NBER Patent Citation } \\
\text { Data File and Patent } \\
\text { Class-SIC } \\
\text { Concordance } \\
\end{array}$ \\
\hline OutsiderAssets $_{\text {it }}$ & Outside Inventor Assets & $\begin{array}{l}\text { The total stock of assets attributable to } \\
\text { the industry in year } t \text { but not } \\
\text { associated with the firm or its rivals }\end{array}$ & Compustat \\
\hline OutsiderCitations it & $\begin{array}{l}\text { Outside Inventor } \\
\text { Citation Productivity }\end{array}$ & $\begin{array}{l}\text { The total stock of patents in the } \\
\text { industry but not associated with firm I } \\
\text { or its rivals accumulated from } 1975 \\
\text { and depreciated at } 15 \% \text { per year }\end{array}$ & $\begin{array}{l}\text { NBER Patent Citation } \\
\text { Data File and Patent } \\
\text { Class-SIC } \\
\text { Concordance } \\
\end{array}$ \\
\hline
\end{tabular}


Table 2: Firm and Rival Characteristics

\begin{tabular}{|c|c|c|c|c|c|c|c|c|c|}
\hline \multirow[b]{3}{*}{ Year } & \multirow[b]{3}{*}{ \# firms ${ }^{\mathrm{a}}$} & & & & & \multicolumn{2}{|c|}{----Counts----- } & \multirow{2}{*}{\multicolumn{2}{|c|}{$\begin{array}{l}\text {--- \# Rivals --- } \\
\text {--- per Firm --- }\end{array}$}} \\
\hline & & \multicolumn{4}{|c|}{-------------Firm Averages*------------- } & & & & \\
\hline & & $\begin{array}{c}\text { Tobin's } \\
\text { q }_{\text {it }}\end{array}$ & $\begin{array}{l}\text { Own- } \\
R \& D_{\text {it }}\end{array}$ & $\begin{array}{l}\text { Own- } \\
\text { Patents }\end{array}$ & $\begin{array}{l}\text { Own- } \\
\text { Citations }_{\text {it }}\end{array}$ & R\&D & patents & Narrow & Broad \\
\hline 1981 & 1613 & 1.33 & 53.6 & 8.98 & 9.20 & 642 & 856 & 10 & 17 \\
\hline 1982 & 1747 & 1.45 & 82.3 & 2.94 & 8.67 & 665 & 978 & 11 & 19 \\
\hline 1983 & 1844 & 1.69 & 65.6 & 3.32 & 8.56 & 685 & 1073 & 12 & 20 \\
\hline 1984 & 1916 & 1.40 & 78.6 & 2.68 & 9.10 & 717 & 1142 & 13 & 21 \\
\hline 1985 & 2053 & 1.57 & 111.1 & 2.22 & 9.14 & 739 & 1196 & 15 & 22 \\
\hline 1986 & 2163 & 1.87 & 99.3 & 2.00 & 9.68 & 807 & 1264 & 16 & 23 \\
\hline 1987 & 2214 & 1.92 & 92.08 & 2.51 & 9.09 & 834 & 1264 & 16 & 23 \\
\hline 1988 & 2210 & 1.71 & 104.7 & 2.23 & 8.80 & 820 & 1264 & 17 & 23 \\
\hline 1989 & 2195 & 1.71 & 108.3 & 2.46 & 7.91 & 801 & 1242 & 17 & 23 \\
\hline 1990 & 2261 & 1.95 & 160.2 & 2.56 & 7.73 & 807 & 1229 & 19 & 25 \\
\hline 1991 & 2357 & 2.22 & 123.1 & 2.13 & 6.84 & 819 & 1289 & 21 & 27 \\
\hline 1992 & 2513 & 1.77 & 142.2 & 2.62 & 6.08 & 843 & 1349 & 23 & 29 \\
\hline 1993 & 2605 & 1.89 & 137.7 & 2.33 & 4.79 & 856 & 1295 & 25 & 31 \\
\hline 1994 & 2689 & 2.26 & 178.8 & 1.65 & 3.56 & 861 & 1340 & 32 & 32 \\
\hline 1995 & 2844 & 3.29 & 180.7 & 1.23 & 2.13 & 865 & 1524 & 33 & 38 \\
\hline 1996 & 2791 & 2.19 & 159.1 & 1.73 & 0.77 & 825 & 1348 & 33 & 37 \\
\hline 1997 & 2419 & 2.69 & 153.3 & 0.99 & 0.35 & 832 & 1140 & 30 & 33 \\
\hline 1998 & 1974 & 2.21 & 202.2 & 1.13 & 0.16 & 123 & 1339 & 24 & 29 \\
\hline 1999 & 2060 & 4.01 & 162.0 & 0.21 & 0.00 & 600 & 1932 & 26 & 30 \\
\hline All yrs & $4168^{\mathrm{C}}$ & 2.10 & 130.2 & 2.28 & 5.65 & $299^{d}$ & $511^{\mathrm{e}}$ & 22 & 27 \\
\hline
\end{tabular}

*Please see Table 1 for an explanation of the units of each of these variables.

${ }^{\mathrm{a}}$ The number of observations is less than the number of firm-years in the sample because of omissions for firms with no $\mathrm{R} \& \mathrm{D}$ stock, patenting stock, or citation-weighted stock in particular years.

${ }^{\mathrm{b}}$ Unless otherwise indicated, this row provide the average value for each column over all firm-years

${ }^{\mathrm{C}}$ Number of unique firms over the 1981-1999 period.

${ }^{\mathrm{d}}$ Number of firms with no R\&D over the entire 1981-1999 period.

${ }^{\mathrm{e}}$ Number of firms with no patents over the entire 1981-1999 period. 
Table 3: Correlation Matrix for all Variables

(a) Narrow Industry Definition

$\begin{array}{llllllllllll}\text { a } & \text { b } & \text { c } & \text { d } & \text { e } & \text { f } & \text { g } & \text { h } & \text { i }\end{array}$

a. Tobin's q $\quad 1.0000$

b. OwnRd

c. OwnPatents

d. OwnCitations

e. RivalRD

f. RivalPatents

g. RivalCitations

h. OutsiderPatents

i. OutsiderCitations
$0.9133 \quad 1.0000$

$\begin{array}{lll}-0.0108 & -0.0089 & 1.0000\end{array}$

$\begin{array}{llll}0.0144 & 0.0036 & -0.0072 & 1.0000\end{array}$

$\begin{array}{llll}0.0382 & 0.0583 & -0.0831 & -0.0243\end{array}$

$\begin{array}{llllll}0.0382 & 0.0583 & -0.0831 & -0.0243 & 1.0000 & \\ -0.0036 & -0.0002 & 0.0209 & 0.0137 & -0.0605 & 1.0000\end{array}$

$\begin{array}{lllllll}0.0156 & -0.0092 & -0.0422 & 0.3710 & 0.0565 & -0.0357 & 1.0000\end{array}$

$\begin{array}{lllllll}0.0033 & -0.0015 & 0.0038 & 0.0144 & 0.0329 & 0.0026 & 0.0272\end{array}$

$\begin{array}{lll}-0.0147 & -0.0106 & 0.0275\end{array}$

0.2592

$-0.1481-0.0079$

0.3608

$0.0490 \quad 1.0000$

(b) Broad Industry Definition

$\begin{array}{lllllllllll}\text { a } & \text { b } & \text { c } & \text { d } & \text { e } & \text { f } & \text { g } & \text { h } & \text { i }\end{array}$
a. Tobin's
b. OwnRd
c. OwnPatents
d. OwnCitations
e. RivalRD
g. RivalCitations
h. OutsiderPatents
i. OutsiderCitations

1.0000

$0.9127 \quad 1.0000$

$\begin{array}{lll}-0.0082 & -0.0067 & 1.0000\end{array}$

$\begin{array}{lll}0.0186 & 0.0068 & -0.0019\end{array}$

$\begin{array}{lll}0.0511 & 0.0652 & -0.0602\end{array}$

$\begin{array}{lll}-0.0035 & -0.0001 & 0.0120\end{array}$

$\begin{array}{lll}0.0204 & -0.0040 & -0.0342\end{array}$

$\begin{array}{lll}0.0076 & 0.0012 & 0.0010\end{array}$

$\begin{array}{lll}-0.0070 & -0.0047 & 0.0058\end{array}$

1.0000

$0.0097 \quad 1.0000$

$\begin{array}{lll}0.0125 & -0.0620 & 1.0000\end{array}$

$\begin{array}{lllll}0.3700 & 0.0963 & -0.0344 & 1.0000\end{array}$

$\begin{array}{lllll}0.0217 & 0.0509 & -0.0013 & 0.0350 & 1.0000\end{array}$

$\begin{array}{llllll}0.0799 & -0.0499 & -0.0040 & 0.1271 & 0.0114 & 1.0000\end{array}$ 


\section{Table 4}

Estimation of the Effect of Existing Rivals' and

Industry Outsider's Innovative Activity on a Focal Firm's Financial-Market Value (a)

Figures in parentheses are standard errors $*=\mathrm{p}<0.10$; $* *=\mathrm{p}<0.05 ; * * *=\mathrm{p}<0.01$ )

\begin{tabular}{|c|c|c|c|c|c|c|}
\hline \multirow{2}{*}{ Variable Name } & \multirow[b]{2}{*}{ Var mean } & \multirow[b]{2}{*}{ (1) } & \multicolumn{2}{|c|}{--Narrow Industry Definition- } & \multicolumn{2}{|c|}{--Broad Industry Definition-- } \\
\hline & & & (2narrow) & (3narrow) & (2broad) & (3broad) \\
\hline \multicolumn{7}{|l|}{ Firm Characteristics } \\
\hline OwnR\&D & 0.408 & $\begin{array}{l}.632 * * * \\
(.022)\end{array}$ & $\begin{array}{l}.513 * * * \\
(.023)\end{array}$ & $\begin{array}{l}.419 * * * \\
(.031)\end{array}$ & $\begin{array}{l}.513 * * * \\
(.023)\end{array}$ & $\begin{array}{l}.457 * * * \\
(.029)\end{array}$ \\
\hline OwnPatents & 8.665 & $\begin{array}{l}-.000 \\
(.000)\end{array}$ & $\begin{array}{l}-.000 \\
(.000)\end{array}$ & $\begin{array}{l}-.000 \\
(.000)\end{array}$ & $\begin{array}{r}-.000 \\
(.000)\end{array}$ & $\begin{array}{l}-.000 * \\
(.000)\end{array}$ \\
\hline OwnCitations & 7.423 & $\begin{array}{l}.021 * * * \\
(.001)\end{array}$ & $\begin{array}{l}.015 * * * \\
(.001)\end{array}$ & $\begin{array}{l}.014 * * * \\
(.002)\end{array}$ & $\begin{array}{l}.015 * * * \\
(.001)\end{array}$ & $\begin{array}{l}.015 * * * \\
(.001)\end{array}$ \\
\hline R\&D dum. & 0.095 & $\begin{array}{l}-.169 * * * \\
(.015)\end{array}$ & $\begin{array}{l}-.125 * * * \\
(.016)\end{array}$ & $\begin{array}{l}-.238 * * * \\
(.028)\end{array}$ & $\begin{array}{l}-.125 * * * \\
(.016)\end{array}$ & $\begin{array}{l}-.156 * * * \\
(.022\end{array}$ \\
\hline Patent dum. & 0.400 & $\begin{array}{l}-.070 * * * \\
(.010)\end{array}$ & $\begin{array}{l}-.071 * * * \\
(.010)\end{array}$ & $\begin{array}{l}-.078 * * * \\
(.015)\end{array}$ & $\begin{array}{l}-.071 * * * \\
(.010)\end{array}$ & $\begin{array}{l}-.076 * * * \\
(.013)\end{array}$ \\
\hline \multicolumn{7}{|l|}{$\begin{array}{l}\text { Characteristics of } \\
\text { Corporate Rivals }\end{array}$} \\
\hline RivalR\&D & 0.190 & & $\begin{array}{l}.541 * * * \\
(.053)\end{array}$ & $\begin{array}{l}.296 * * * \\
(.073)\end{array}$ & $\begin{array}{l}.541 * * * \\
(.053)\end{array}$ & $\begin{array}{l}.368 * * * \\
(.065)\end{array}$ \\
\hline RivalPatents & 5.002 & & $\begin{array}{l}.000 \\
(.000)\end{array}$ & $\begin{array}{l}.000 * \\
(.000)\end{array}$ & $\begin{array}{l}.000 \\
(.000)\end{array}$ & $\begin{array}{l}.000 * \\
(.000)\end{array}$ \\
\hline RivalCitations & 6.920 & & $\begin{array}{l}.028 * * * \\
(.003)\end{array}$ & $\begin{array}{l}.046 * * * \\
(.005)\end{array}$ & $\begin{array}{l}.028 * * * \\
(.003)\end{array}$ & $\begin{array}{l}.043 * * * \\
(.004)\end{array}$ \\
\hline R\&D dum. & 0.004 & & $\begin{array}{l}.069 \\
(.067)\end{array}$ & $\begin{array}{l}-.051 \\
(.115)\end{array}$ & $\begin{array}{l}.069 \\
(.067)\end{array}$ & $\begin{array}{l}-.059 \\
(.094)\end{array}$ \\
\hline Patent dum. & 0.007 & & $\begin{array}{l}.112 * \\
(.059)\end{array}$ & $\begin{array}{l}.140 * \\
(.085)\end{array}$ & $\begin{array}{l}.112 * \\
(.059)\end{array}$ & $\begin{array}{l}.133 * \\
(.076)\end{array}$ \\
\hline OwnR\&D * RivalR\&D & 0.120 & & $\begin{array}{l}-.039 * * * \\
(.007)\end{array}$ & $\begin{array}{l}-.008 \\
(.008)\end{array}$ & $\begin{array}{l}-.039 * * * \\
(.007)\end{array}$ & $\begin{array}{l}-.011 \\
(.007)\end{array}$ \\
\hline \multicolumn{7}{|l|}{$\begin{array}{l}\text { Characteristics of Outside } \\
\text { Inventors }\end{array}$} \\
\hline OutsiderPatents & 0.590 & & & $\begin{array}{l}.004 * \\
(.003)\end{array}$ & & $\begin{array}{l}.008 * * \\
(.016)\end{array}$ \\
\hline OutsiderCitations & 5.552 & & & $\begin{array}{l}-.009 * * * \\
(.001)\end{array}$ & & $\begin{array}{l}-.001 * * * \\
(.000)\end{array}$ \\
\hline Patent dum & 0.001 & & & (b) & & $\begin{array}{l}-.173 \\
(.230)\end{array}$ \\
\hline Constant & & $\begin{array}{l}-.186 * * * \\
(.026)\end{array}$ & $\begin{array}{l}-.385 * * * \\
(.031)\end{array}$ & $\begin{array}{l}-.351 * * * \\
(.051)\end{array}$ & $\begin{array}{l}-.385 * * * \\
(.031)\end{array}$ & $\begin{array}{l}-.443 * * * \\
(.093)\end{array}$ \\
\hline Year effects & & Incl. & Incl. & Incl. & Incl. & Incl. \\
\hline $\mathrm{N}$ & & 24815 & 23665 & 10739 & 23665 & 13227 \\
\hline $\mathrm{R}^{2}$ & & .1518 & .1612 & .1516 & .1612 & .1630 \\
\hline Adj. $R^{2}$ & & .1510 & .1602 & .1492 & .1602 & .1610 \\
\hline
\end{tabular}

(a) Computational limitations prevented the inclusion of firm fixed effects. To control for firm effects, we subtracted from the dependent variables the average of each firm's performance intertemporally (prior to taking logs); as a result, the dependent variables represent, for each firm, the abnormal return for the firm in the year.

(b) dropped for colinearity 


\section{Table 5}

Replication on Subsets Based on Yale Survey

Figures in parentheses are standard errors $*=\mathrm{p}<0.10$; $* *=\mathrm{p}<0.05$; *** $=\mathrm{p}<0.01$ )

$\begin{array}{cccc}\text {--Patent Protection-- } & \text {--Patent Protection-- } & \text {--Complementary-- } & \text {--Complementary-- } \\ \text { (Above Avg.) } & \text { (Below Avg.) } & \text { Asset Strength } & \text { Asset Strength }\end{array}$

(Above Avg.) (Below Avg.)

-Narrow- --Broad-- -Narrow- --Broad-- -Narrow- --Broad-- $\quad$-Narrow- --Broad--

\begin{tabular}{|c|c|c|c|c|c|c|c|c|}
\hline Variable Name & $(1)$ & (2) & (3) & (4) & (5) & (6) & (7) & $(8)$ \\
\hline \multicolumn{9}{|l|}{ Firm Characteristics } \\
\hline OwnR\&D & $\begin{array}{l}.862 * * * \\
(.091)\end{array}$ & $\begin{array}{l}.865 * * * \\
(.090)\end{array}$ & $\begin{array}{l}.162 * * * \\
(.055)\end{array}$ & $\begin{array}{l}.195 * * * \\
(.056)\end{array}$ & $\begin{array}{l}.050 \\
(.055)\end{array}$ & $\begin{array}{l}.050 \\
(.055)\end{array}$ & $\begin{array}{l}1.149 * * * \\
(.108)\end{array}$ & $\begin{array}{l}.195 * * * \\
(.056)\end{array}$ \\
\hline OwnPatents & $\begin{array}{l}.000 \\
(.000)\end{array}$ & $\begin{array}{l}.000 \\
(.000)\end{array}$ & $\begin{array}{l}-.000 \\
(.000)\end{array}$ & $\begin{array}{l}-.000 \\
(.000)\end{array}$ & $\begin{array}{l}.003 \\
(.002)\end{array}$ & $\begin{array}{l}.003 \\
(.002)\end{array}$ & $\begin{array}{l}-.000 \\
(.000)\end{array}$ & $\begin{array}{l}-.000 \\
(.000)\end{array}$ \\
\hline OwnCitations & $\begin{array}{l}.031 * * * \\
(.006)\end{array}$ & $\begin{array}{l}.031 * * * \\
(.006)\end{array}$ & $\begin{array}{l}.023 * * * \\
(.003)\end{array}$ & $\begin{array}{l}.025 * * * \\
(.003)\end{array}$ & $\begin{array}{l}.024 * * * \\
(.003)\end{array}$ & $\begin{array}{l}.024 * * * \\
(.004)\end{array}$ & $\begin{array}{l}.025 * * * \\
(.005)\end{array}$ & $\begin{array}{l}.025 * * * \\
(.003)\end{array}$ \\
\hline R\&D dum. & $\begin{array}{l}-.122 * * \\
(.059)\end{array}$ & $\begin{array}{l}-.131 * * \\
(.056)\end{array}$ & $\begin{array}{l}-.317 * * * \\
(.050)\end{array}$ & $\begin{array}{l}-.333 \text { *** } \\
(.048)\end{array}$ & $\begin{array}{l}-.432 * * * \\
(.067)\end{array}$ & $\begin{array}{l}-.432 * * * \\
(.067)\end{array}$ & $\begin{array}{l}-.143^{* * *} \\
(.049)\end{array}$ & $\begin{array}{l}-.333 \text { *** } \\
(.048)\end{array}$ \\
\hline Patent dum. & $\begin{array}{l}.021 \\
(.030)\end{array}$ & $\begin{array}{l}.026 \\
(.029)\end{array}$ & $\begin{array}{l}-.090 * * * \\
(.024)\end{array}$ & $\begin{array}{l}.085 * * * \\
(.024)\end{array}$ & $\begin{array}{l}-.076 * * * \\
(.025)\end{array}$ & $\begin{array}{l}-.076 * * * \\
(.025)\end{array}$ & $\begin{array}{l}.014 \\
(.028)\end{array}$ & $\begin{array}{l}-.085 * * * \\
(.024)\end{array}$ \\
\hline \multicolumn{9}{|l|}{$\begin{array}{l}\text { Characteristics of } \\
\text { Corporate Rivals }\end{array}$} \\
\hline RivalR\&D & $\begin{array}{l}1.789 * * * \\
(.269)\end{array}$ & $\begin{array}{l}1.692 * * * \\
(.251)\end{array}$ & $\begin{array}{l}-.305 * * * \\
(.102)\end{array}$ & $\begin{array}{l}-.253 * * \\
(.101)\end{array}$ & $\begin{array}{l}-.123 \\
(.016)\end{array}$ & $\begin{array}{l}-.123 * * \\
(.114)\end{array}$ & $\begin{array}{l}.944 * * * \\
(.181)\end{array}$ & $\begin{array}{l}-.253 * * \\
(.101)\end{array}$ \\
\hline RivalPatents & $\begin{array}{l}.000 \\
(.000)\end{array}$ & $\begin{array}{l}.000 \\
(.000)\end{array}$ & $\begin{array}{l}.000 \\
(.002)\end{array}$ & $\begin{array}{l}-.000 \\
(.001)\end{array}$ & $\begin{array}{l}-.031 * * \\
(.013)\end{array}$ & $\begin{array}{l}-.031 * * \\
(.013)\end{array}$ & $\begin{array}{l}.000 \\
(.000)\end{array}$ & $\begin{array}{l}.000 \\
(.000)\end{array}$ \\
\hline RivalCitations & $\begin{array}{l}.094 * * * \\
(.020)\end{array}$ & $\begin{array}{l}.093 * * * \\
(.020)\end{array}$ & $\begin{array}{l}.050 * * * \\
(.009)\end{array}$ & $\begin{array}{l}.051 * * * \\
(.009)\end{array}$ & $\begin{array}{l}.054 * * * \\
(.010)\end{array}$ & $\begin{array}{l}.054 * * * \\
(.010)\end{array}$ & $\begin{array}{l}.064 * * * \\
(.014)\end{array}$ & $\begin{array}{l}.051 * * * \\
(.009)\end{array}$ \\
\hline R\&D dum. & $\begin{array}{l}.800 * * * \\
(.282)\end{array}$ & $\begin{array}{l}.801 * * * \\
(.278)\end{array}$ & (a) & (a) & (a) & (a) & $\begin{array}{l}.658 * * \\
(.282)\end{array}$ & (a) \\
\hline Patent dum. & (a) & (a) & $\begin{array}{l}-.093 \\
(.168)\end{array}$ & $\begin{array}{l}-.098 \\
(.165)\end{array}$ & $\begin{array}{l}-.263 \\
(.235)\end{array}$ & $\begin{array}{l}-.263 \\
(.235)\end{array}$ & $\begin{array}{l}.130 \\
(.207)\end{array}$ & $\begin{array}{l}-.098 \\
(.165)\end{array}$ \\
\hline OwnR\&D * RivalR\&D & $\begin{array}{l}-.175 * * * \\
(.018)\end{array}$ & $\begin{array}{l}-.173 * * * \\
(.018)\end{array}$ & $\begin{array}{l}-.145 * * * \\
(.047)\end{array}$ & $\begin{array}{l}-.157 * * * \\
(.045)\end{array}$ & $\begin{array}{l}-.076 \\
(.066)\end{array}$ & $\begin{array}{l}-.076 \\
(.066)\end{array}$ & $\begin{array}{l}-.192 * * * \\
(.018)\end{array}$ & $\begin{array}{l}-.157 * * * \\
(.045)\end{array}$ \\
\hline \multicolumn{9}{|l|}{$\begin{array}{l}\text { Characteristics of } \\
\text { Outsider Inventors }\end{array}$} \\
\hline OutsiderPatents & $\begin{array}{l}.005 \\
(.003)\end{array}$ & $\begin{array}{l}.005 \\
(004)\end{array}$ & $\begin{array}{l}-.013 \\
(.021)\end{array}$ & $\begin{array}{l}.017 \\
(.019)\end{array}$ & $\begin{array}{l}-.062 * * * \\
(.016)\end{array}$ & $\begin{array}{l}-.062 * * * \\
(.016)\end{array}$ & $\begin{array}{l}.008 * \\
(.004)\end{array}$ & $\begin{array}{l}.017 \\
(.019)\end{array}$ \\
\hline OutsiderCitations & $\begin{array}{l}-.005 \\
(.003)\end{array}$ & $\begin{array}{l}-.007 * * \\
(.003)\end{array}$ & $\begin{array}{l}.041 * * * \\
(.012)\end{array}$ & $\begin{array}{l}.001 \\
(.002)\end{array}$ & $\begin{array}{l}.065 * * * \\
(.017)\end{array}$ & $\begin{array}{l}.065 * * * \\
(.017)\end{array}$ & $\begin{array}{l}-.005 \\
(.003)\end{array}$ & $\begin{array}{l}.001 \\
(.002)\end{array}$ \\
\hline Patent dum & (b) & (b) & (b) & (b) & (b) & (b) & (b) & (b) \\
\hline Constant & $\begin{array}{l}-.812 * * * \\
(.122)\end{array}$ & $\begin{array}{l}-.810 * * * \\
(.115)\end{array}$ & $\begin{array}{l}-.673 * * * \\
(.100)\end{array}$ & $\begin{array}{l}-.496 * * * \\
(.078)\end{array}$ & $\begin{array}{l}-.766 * * * \\
(.112)\end{array}$ & $\begin{array}{l}-.766 * * * \\
(.112)\end{array}$ & $\begin{array}{l}-.711 * * * \\
(.105)\end{array}$ & \\
\hline Year effects & Incl. & Incl. & Incl. & Incl. & Incl. & Incl. & Incl. & Incl. \\
\hline $\mathrm{N}$ & 3010 & 3123 & 3415 & 3593 & 3112 & 3112 & 3344 & 3593 \\
\hline $\mathrm{R}^{2}$ & .2721 & .2765 & .1385 & .1353 & .1510 & .1510 & .2704 & .1353 \\
\hline Adj. $R^{2}$ & .2647 & .2695 & .1308 & .1280 & .1427 & .1427 & 2636 & .1280 \\
\hline
\end{tabular}

(a) Computational limitations prevented the inclusion of firm fixed effects. To control for firm effects, we subtracted from the dependent variables the average of each firm's performance intertemporally (prior to taking logs); as a result, the dependent variables represent, for each firm, the abnormal return for the firm in the year.

(b) dropped for colinearity 


\section{Appendix A: Calculation of Tobin's q}

In this study, we calculate Tobin's q for each firm-year in our sample using the procedure in Lindenberg and Ross (1981) and Salinger (1984) as updated in Lang and Stulz (1994) and McGahan (1999). This approach uses information from publicly filed financial statements as originally recorded in both the Active and Research files of the Compustat Corporate dataset.

Tobin's q for firm i in year t is defined as: $q_{i t}=\frac{\text { MarketValue }_{i t}}{\text { BookValue }_{i t}}$

The numerator is the sum of:

(i) The market value of year-end common equity times the number of shares outstanding at end of year.

(ii) The book value of preferred stock as reported at the end of the year.

(iii) The book value of debt.

The denominator is the replacement value of the firm's booked assets (sometimes called the salvage value of the firm's assets). It equals the sum of:

(i) The book value of cash, investments, accounts receivables, trade receivables, other current assets, and all other assets except for inventories and net property, plant and equipment.

(ii) The replacement value of inventory, which is calculated by imputing annual purchases given the method of inventory accounting (i.e., LIFO, FIFO, average cost, etc.). This process is based on the assumption that in 1970, which is substantially prior to the first year analyzed (i.e, 1981), the book value of inventory equaled its replacement value. Then for every subsequent year after 1970, the replacement value of inventory is calculated as the value in the prior year reassessed for inflation plus purchases and less the Cost of Goods Sold. Each of these values are constructed by LIFO accounting and each is inflation-adjusted by the wholesale price index as reported in the Economic Report of the President. This is the same approached used by Lindenberg and Ross (1981), Lang and Stulz (1994) and McGahan (1999), and is considered standard in the literature.

(iii) The replacement value of plant, property and equipment (PP\&E), which is calculated by a similar procedure. First, for 1970, the replacement value of PP\&E is assumed to equal its book 
value. Then for every subsequent year, the schedule of acquisitions of PP\&E is imputed by examining changes in year-end values and reported depreciation. Finally, for every subsequent year after 1970, the replacement value of PP\&E is calculated as the value in the prior year reassessed for inflation plus purchases and less depreciation of 5\%. Each of these values is inflation-adjusted by the producer price index as reported in the Economic Report of the President. See McGahan (1999) for more details.

\section{Appendix B: Construction and Testing of a Patent Class-SIC Concordance}

When the U.S. Patent and Trademark Office (UPSPTO) grants a patent application, the granting officer classifies it according to the U.S. Patent Classification (USPC) system and the International Patent Classification (IPC) system. Patent classes are based on characteristics of the underlying technology rather than on industry characteristics, and thus do not correspond to industry-based classification such as the SIC system. The lack of correspondence between USPC and SIC classes has made it difficult for researchers to link patent data to industry-specific data. In the early 1980s, the Office of Technology Assessment and Forecasting (OTAF) developed a concordance linking USPC and SIC classes (Office of Technology Assessment and Forecast 1985). However, this concordance is limited to 57 categories primarily aggregated at the 2- and 3-digit level, insufficiently detailed for many research goals. Scholars have criticized OTAF’s imposition of a one-to-one correspondence between USPC and SIC (Griliches 1990).

An ideal solution would be for the USPTO to assign SIC codes, in addition to a USPC code, to each patent. While it is unlikely that the USPTO will assume this burden in the near future, this was in fact done by the Canadian Patent Office (CPO) from 1978 through 1994 (Ellis 1981). The CPO assigned each patent granted in Canada to its appropriate patent class, using the International Patent Classification (IPC) system rather than the USPC, and also assigned the patent to the appropriate 4-digit Canadian SIC of Use and, if applicable, SIC of Manufacture.

Using the CPO database for 1978-1994 (covering more than 200,000 patents), we calculate the frequency with which patents in each patent class were assigned to each SIC of Use and SIC of Manufacture. We then use the resulting frequency distribution as a probability distribution to relate patent 
classes to SIC codes. For example, suppose the CPO granted 576 patents assigned to IPC class A01N between 1978 and 1994, and assigned these patents to SICs as follows:

$\begin{array}{llcllr}\text { SIC of Use } & \# & \% & \text { SIC of Mfre } & \# & \% \\ 3711 & 213 & 37 & 3194 & 340 & 59 \\ 3712 & 127 & 22 & 3035 & 115 & 20 \\ 3194 & 115 & 20 & 3011 & 37 & 6 \\ 3799 & 52 & 9 & 3814 & 34 & 6 \\ \text { etc. } & \ldots & \ldots & \text { etc. } & \ldots & \ldots\end{array}$

Based on these frequency distributions, any single patent assigned to A01N during the 1978-1994 period has probability 0.37 of being assigned to SIC of Use 3711, 0.22 of being assigned to SIC 3712, etc. If one assumes that patents are assigned and exploited according to similar processes in the U.S. and Canada, then the same probability distribution will hold for patents assigned in the U.S. We can thus convert each patent issued in the U.S. to its corresponding probability-weighted SICs.

Of course, there are additional complications. Since the CPO classifies patents according to the IPC rather than the USPC, we use the IPC assignment that the U.S Patent Examiner adds for each patent. U.S. examiners are typically less confident in IPC assignments than in their USPC assignments. Further, the CPO classifies patents according to the Canadian SIC system rather than the U.S. system. To link the patent-SIC probability distributions to the U.S. SIC system, we use the Canada Statistical Office’s Concordance Between the Industrial Classifications of Canada and the United States. This enables us to convert Canadian SICs codes to U.S. equivalents. However, some Canadian SICs are matched to multiple U.S. SICs. In such cases, we assume that patents assigned to the Canadian SIC are equally likely to be useful across all U.S. SICs to which the Canadian SIC is matched. Third, the U.S. SIC system underwent a substantive update in 1987 . To facilitate the analysis in this study, we convert all pre-1980 SIC data to the relevant 1987 SIC codes. Each of these steps likely introduces noise into our data.

Without being able to compare the above-described concordance's assignment to the "true" industry assignment of a U.S. patent, is it difficult to judge the accuracy of the above procedure. There is no systematic source for the "true" assignment of U.S. patents. However, in the late 1970s, Scherer supervised a monumental project in which over 15,000 U.S. patents were individually assigned to a 3- or 4digit SIC code. Scherer subsequently tested the accuracy of the OTAF's concordance by comparing its SIC-code assignment to those assigned in his project for a sample of 99 patents selected from the 15,000 
(Scherer 1982). The OTAF assignments matched Scherer's at the 3-digit level for 50 patents, and at the 2digit level for 67 patents.

To test the accuracy of the above-described concordance, Silverman (2002) replicated Scherer’s comparison using the same 99 patents. Silverman found a much higher match rate than was achieved by the OTAF -- up to 68 matches at the 4-digit level, 74 matches at the 3-digit level, and 90 matches at the 2digit level, depending on the criteria used to calculate a match. The concordance has been used in several studies, including McGahan and Silverman (2001) and Mowery and Ziedonis (2001). See Silverman (2002, chapter 4) for more details on the construction of the concordance.

\section{Appendix C: Models that Include Industry Effects}

The main result reported in this paper - that investors respond differently based on the identity of the innovator - suggests that industry structure plays a critical role in determining the impact of innovation on firm performance. To test this idea, we obtained results including a series of industry dummy variables to represent industry fixed effects. These variables broadly represent the influence of all industry-specific factors - including the presence of corporate rivals and the existence of entry barriers to innovative outsiders - on the protagonist firm's performance. They are not included in the main analyses because they carry the potential to obscure relationships embedded in the industry structure such as the influence of rival innovation on the protagonist firm's financial-market value. The influence of rival innovation would become obscured by the industry fixed effects if the financial-market performance of all firms within an industry is affected similarly by spillovers. Similarly, the influence of outsider innovation would be obscured by the industry fixed effects if the performance of all firms within an industry is affected similarly by outsider innovation.

The results indicate that, when industry effects are included, the coefficients on the rival patent stock lose significance, which suggests that firms within industries are similarly affected by regular innovation across rivals. The results on rival citation stock continue to be positive and significant, however, which indicates that differences arise across firms in their responses to rival innovation. This is important because it provides some support for the idea that ordinary patenting tends to improve the performance of the corporate rival with the invention at the expense of all of its rivals, while important 
patenting by a corporate rival has an effect that also depends on the competitive positioning of the protagonist firm.

The coefficients on outsider patent and citation stocks become insignificant except in the case of the narrow industry definition, where the outsider patent stock becomes insignificant. This finding points to the possibility that entry barriers protect incumbents similarly against outsider innovation, except when innovation is regular and the industry is conceptualized narrowly. This exception indicates that firms within the same primary SIC are differentially affected by the regular innovation of outsiders, perhaps because firms differ in their capabilities for appropriating the benefits to these innovations.

When fixed industry effects are included but outsider innovation is excluded, the impact of the firm's own innovative activity is robust across the models. Consistent with the full models, the coefficients on rival innovation are insignificant, which again points to the powerful mediating influence of industry structure on the abilities of protagonist firms to benefit from rivals' breakthroughs. 


\section{References}

Anderson, P. and Tushman, M. "Technological discontinuities and dominant designs: a cyclical model of technological change.” Administrative Science Quarterly, Vol. 35 (1990), pp. 604-633.

Arora, A. and Merges, R.P. "Specialized supply firms, property rights, and firm boundaries.” Industrial and Corporate Change, Vol. 13 (2004), pp. 451-475.

Austin, D.H. "An event study approach to measuring innovative output: The case of biotechnology,” American Economic Review, Vol. 83 (1993), pp. 253-258.

Austin, D.H. "Patents, spillovers and competition in biotechnology: an event study," Resources for the Future, Discussion Paper 00-53 (November 2000).

Cockburn, I. and Griliches, Z. "Industry effects and appropriability measures in the stock market's valuation of R\&D and patents,” American Economic Review, Vol 78 (1988), pp. 419-423.

Cohen, W.M. and Levinthal, D.A. “Absorptive Capacity: A New Perspective on Learning and Innovation, Administrative Science Quarterly, Vol. 35 (1990), 128-152.

Cohen, W.M., Goto, A., Nagata, A., Nelson, R.R., and Walsh, J.P. "R\&D spillovers, patents and the incentives to innovate in Japan and the United States,” Research Policy, Vol. 31 (2002), pp. 1349-1367.

Dixit, A. “A general model of R\&D competition and policy,” Rand Journal of Economics, Vol. 19 (1988), pp. 317-326.

Dushnitsky G, Lenox M.J. “When do firms undertake R\&D by investing in new ventures?” Strategic Management Journal, Vol. 26 (2005), pp. 947-965.

Ellis, E.D. "Canadian patent data base: The philosophy, construction, and uses of the Canadian patent data base PATDAT,” World Patent Information, Vol. 3 (1981), pp. 13-18.

Furman, J., M. Kyle, I. Cockburn and R. Henderson, "Private and Public Spillovers, Location, and the Productivity of Pharmaceutical Research,” working paper (2004), forthcoming in Annales d'Economie et Statistique

Gans, J. and Stern, S. "Incumbency and R\&D incentives: Licensing the gale of creative destruction,” Journal of Economics and Management Strategy, Vol. 9 (2000), pp. 485-511.

Griliches, Z. “Market value, R\&D, and patents,” Economics Letters, Vol. 7 (1981), pp. 183-187.

Griliches, Z. "Patent statistics as economic indicators: A survey,” Journal of Economic Literature, Vol. 28 (1990), pp. 1661-1707.

Hall, B.H. “Innovation and Market Value,” NBER Working Paper \#6984 (1999). [Published in 2000: In Barrell, R., G. Mason, and M. O’Mahoney (eds.), Productivity, Innovation, and Economic Performance, Cambridge, Cambridge University Press.]

Hall, B.H., Jaffe, A.B. and Trajtenberg, M. "The NBER patent citations data file: Lessons, insights, and methodological tools,” NBER Working Paper \#8498 (2001). 
Hall, B.H., Jaffe, A.B., and Trajtenberg, M. “Market value and patent citations,” Rand Journal of Economics, Vol. 36 (2005), pp. 16-38.

Harhoff, D., Narin, F., Scherer, F.M., and Vopel K. "Citation frequency and the value of patented inventions,” Review of Economics and Statistics, Vol. 81 (1999), pp. 511-515.

Henderson, R.M. "Underinvestment and Incompetence as Responses to Radical Innovation: Evidence from the Photolithographic Alignment Equipment Industry,” Rand Journal of Economics, Vol. 24 (1993), pp. 248-270.

Jaffe, A.B. "Technological opportunity and spillovers of R\&D: Evidence from firms' patents, profits, and market value,” American Economic Review, Vol. 76 (1986), pp.

Jaffe, A.B. “Characterizing the 'technological position' of firms, with application to quantifying technological opportunity and research spillovers,” Research Policy, Vol. 18 (1989), pp. 87-97.

Lang, L.H.P. and Stulz, R.M. “Tobin’s Q, corporate diversification, and firm performance,” Journal of Political Economy, Vol. 102 (1994), pp. 1248-1280.

Levin, R.C., Cohen, W.M. and Mowery, D.C., "R\&D Appropriability, Opportunity, and Market Structure: New Evidence on Some Schumpeterian Hypotheses," American Economic Review , pp. 20-24 (May, 1985)

Levin, R.C. and Reiss, P.C. “Cost-reducing and demand-creating R\&D with spillovers,” Rand Journal of Economics, Vol. 19 (1988), pp. 538-556.

Levin, R.C., Klevorick, A.K., Nelson, R.R. and Winter, S.G., “Appropriating the returns from industrial research and development,” Brookings Papers on Economic Activity, Vol. 3 (1987), pp. 783-833.

Lindenberg, E.B. and Ross, S.A. “Tobin’s q ratio and industrial organization,” Journal of Business, Vol. 54 (1981), pp. 1-32.

Mazzoleni, R. and Nelson, R.R. "The benefits and costs of strong patent protection: A contribution to the current debate,” Research Policy, Vol. 27 (1998), pp. 273-284.

McGahan, A.M. “The Performance of U.S. Corporations,” Journal of Industrial Economics , Vol 47 (1999), pp. 373-398.

McGahan, A.M. and Silverman, B.S. "How does innovative activity change as industries mature" International Journal of Industrial Organization, Vol. 19 (2001), pp. 1141-1160.

Megna, P. and Klock, M. “The impact of intangible capital on Tobin's q in the semiconductor industry,” American Economic Review, Vol. 83 (1993), pp. 265-269.

Merges, R., Patent Law and Public Policy (Charlottesville, VA: Lexis Law Pub., 1997)

Mowery, D.C. and Ziedonis, A.A. "The geographic reach of market and non-market channels of technology transfer: Comparing citations and licenses of university patents,” NBER Working Paper \#8568, National Bureau of Economic Research, Cambridge, MA (2001). 
Office of Technology Assessment and Forecast. "Review and Assessment of the OTAF Concordance Between the U.S. Patent Classification and the Standard Industrial Classification Systems: Final Report," unpublished manuscript (1985).

Oxley, J.E. “Appropriability hazards and governance in strategic alliances: A transaction cost approach.” Journal of Law and Economics, Vol. 13 (1997), pp. 387-409.

Pakes, A. “On patents, R\&D, and the stock market rate of return,” Journal of Political Economy, Vol. 93 (1985), pp. 390-409.

Pisano, G.P. "The research-and-development boundaries of the firm: An empirical analysis." Administrative Science Quarterly, Vol. 35 (1990), pp. 153-176.

Reinganum, J.F. “Uncertain innovation and the persistence of monopoly,” American Economic Review, Vol. 73 (1983), pp. 741-748.

Reinganum, J.F. “The timing of innovation: Research, development, and diffusion,” in R. Schmalensee and R. D. Willig, editors, Handbook of Industrial Organization, pages 850-908. North-Holland (1989).

Reitzig, M. "Improving patent valuations for management purposes: Validating new indicators by analysing application rationales.” Research Policy, Vol. 33 (2004), pp. 939-957.

Rothaermel, F.T. "Complementary assets, strategic alliances, and the incumbent's advantage: An empirical study of industry and firm effects in the biopharmaceutical industry.” Research Policy, Vol. 30 (2001), pp. 1235-1251.

Salinger, M.A. “Tobin’s q, unionization, and the concentration-profits relationship,” Rand Journal of Economics, Vol. 15 (1984), pp. 159-170.

Scherer, F.M. "The Office of Technology Assessment and Forecast industry concordance as a means of identifying industry technology origins,” World Patent Information, Vol. 4 (1982), pp. 2-17

Silverman, B.S. "Technological resources and the direction of corporate diversification: Toward an integration of transaction cost economics and the resource-based view,” Management Science, Vol. 45 (1999), pp. 1109-1124.

Silverman, B.S. Technical Assets and the Logic of Corporate Diversification, London: Routledge Press (2002).

Teece, D., “Profiting from Innovation,” Research Policy (1986).

Tripsas, M. "Surviving Radical Technological Change through Dynamic Capability: Evidence from the Typesetter Industry." Industrial and Corporate Change 6, no. 2 (1997): 341-377. 